Portland State University

PDXScholar

5-23-1977

\title{
A Descriptive Study of Some Problems of Widows in Portland, Oregon
}

Kathleen Marsha Davis

Portland State University

Gail Petchesky

Portland State University

Follow this and additional works at: https://pdxscholar.library.pdx.edu/open_access_etds

Part of the Family, Life Course, and Society Commons, and the Social Work Commons Let us know how access to this document benefits you.

\section{Recommended Citation}

Davis, Kathleen Marsha and Petchesky, Gail, "A Descriptive Study of Some Problems of Widows in Portland, Oregon" (1977). Dissertations and Theses. Paper 1888.

https://doi.org/10.15760/etd.1887

This Thesis is brought to you for free and open access. It has been accepted for inclusion in Dissertations and Theses by an authorized administrator of PDXScholar. Please contact us if we can make this document more accessible: pdxscholar@pdx.edu. 
A DESCRIPTIVE STUDY OF

SOME PROBLEMS OF WIDOWS

IN PORTLAND, OREGON

by

KATHLEEN MARSHA DAVIS

and

GAIL PETCHESKY

A practicum submitted in partial fulfillment of the

requirements for the degree of

MASTER OF SOCIAL WORK

Portland State University

1977 
The advisor approved the practicum of Kathleen Marsha Davis and Gail Petchesky, presented on May 23, 1977.

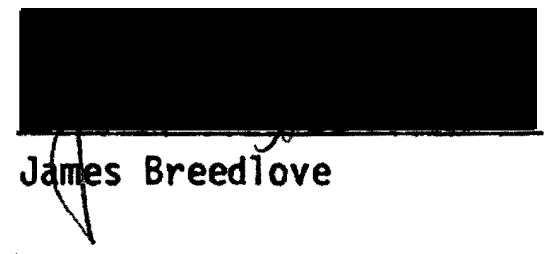


ACKNOWLEDGEMENTS

We wish to express our special thanks and appreciation to Jim Breedlove for his patience, direction and encouragement, to Larry Whitaker for contributing his time and always being available to us as a resource person, to all the widows who were willing to share with us their experiences, which made this study possible, to Ken Davis for his unl imited patience and support and to each other for the warm relationship we developed during the last year. 
TABLE OF CONTENTS

PAGE

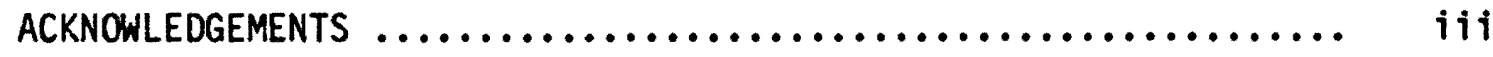

CHAPTER

I DESCRIPTION OF THE STUDY ..................... 1

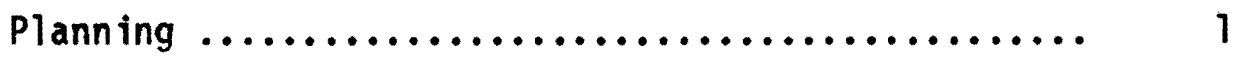

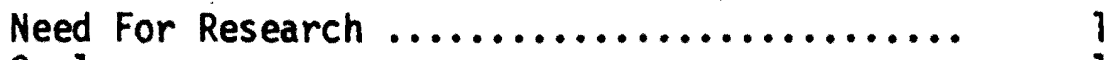

Goals ................................ I

Guidel ines (Assumptions) For the Develop-

ment of the Study ................... 1

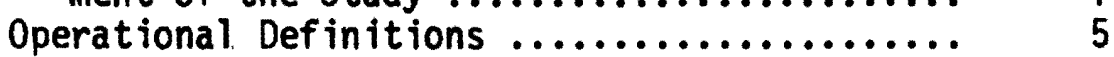

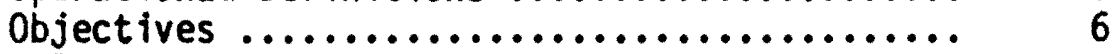

Pilot Study ........................ 6

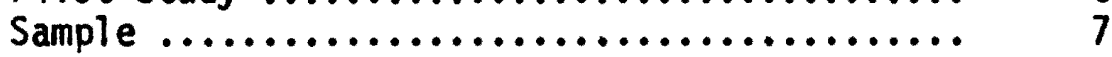

Measurement and Data Collection ............... 8

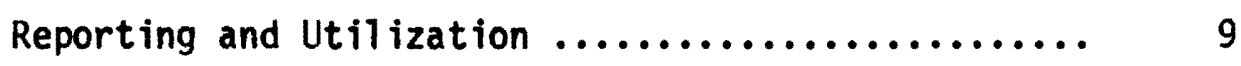

II LITERATURE REVIEW ........................ 10

Introductory Remarks and Scope of Widowhood Problems 10

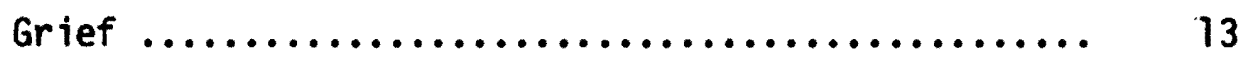

Stages of Grief $\ldots \ldots \ldots \ldots \ldots \ldots \ldots \ldots \ldots \ldots \ldots$

Role Identity of the Widow ................ 17

Problems of Widowhood $\ldots \ldots \ldots \ldots \ldots \ldots \ldots \ldots \ldots \ldots . \ldots \ldots$

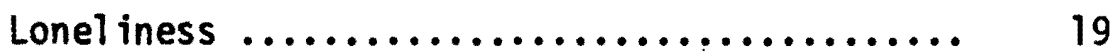

Unfriendly Friends ................... 20

Feel ing Like A Fifth theel ................ 20

Finances ........................... 20

Widowhood and Employment ............... 21

Physical and Mental Health of the Widow ......... 22 
CHAPTER

Models and Examples of Service Programs Available for Widowed ............................. 23

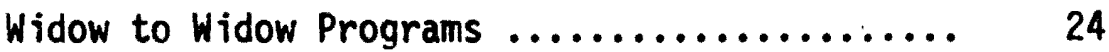

Widowed Service Line ..................... 25

Lecture Format of Widow Programs ........... 28

III PROBLEMS OF WIDOWHDOD $\ldots \ldots \ldots \ldots \ldots \ldots \ldots \ldots \ldots \ldots \ldots \ldots \ldots$

IV CULTURAL ROLES $\ldots \ldots \ldots \ldots \ldots \ldots \ldots \ldots \ldots \ldots \ldots \ldots \ldots \ldots \ldots$

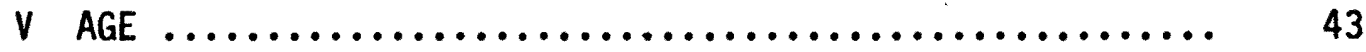

VI FINANCES $\ldots \ldots \ldots \ldots \ldots \ldots \ldots \ldots \ldots \ldots \ldots \ldots \ldots \ldots \ldots \ldots \ldots$

VII STRESS AND SOCIAL NETWORK ................... 56

VIII SUGGESTIONS FOR NEW WIDOWS ................... 62

IX SOCIAL SERVICES FOR WIDOWS .................. 67

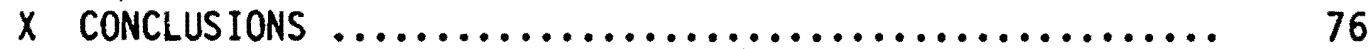

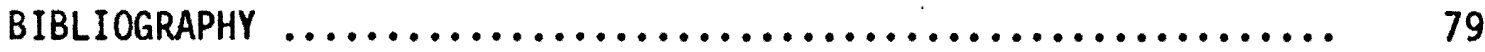

APPENDIX A ZUNG SELF-RATING DEPRESSION SCALE .............. 81

APPENDIX B SOCIAL READJUSTMENT RATING SCALE .............. 82

APPENDIX C PILOT STUDY QUESTIONNAIRE ................... 84

APPENDIX D QUESTIONNAIRE ......................... 85 


\section{CHAPTER I}

\section{DESCRIPTION OF THE STUDY}

\section{PLANNING}

\section{Need For Research}

Widowhood is an inevitable phase of the life cycle for three out of every four married women. It is apparent by the lack of research about widowhood that it has been neglected as a developmental phase in the life cycle. Presently there are ten million widows in this country and their numbers are increasing each year. It is appalling that with a population this large, little attention has been directed towards research about widowhood. Other than recognizing that the widow may have financial problems for which Social Security provides assistance, few people realize what it means to be widowed. For these reasons, we decided to study the problems of widowhood.

\section{Goals}

The purpose of this study is to examine the problems involved in widowhood and what might be helpful in dealing with them. In addition, another goal of this study is to increase public awareness about the plight of the widow.

\section{Guidel ines (Assumptions) For the Development of the Study}

This study focuses upon six assumptions.

The first assumption is, "If stress is high and the availability 
of a social network is not well developed, widowhood adjustment will be difficult." Stress is defined as new life events that occur for each individual requiring changes in social roles. These life events may include: death of a spouse, change in financial state, change in residence, and, so forth. A new life event causes change in the individuals on-going life patterns, and, therefore, requires the individual to develop new adaptive or coping behavior to accommodate the new life event. As for the availability of the social network system, it will be defined by the amount of social contact (phone calls, letters and personal visits) that the widow had with members of her immediate family, relatives and friends.

Obviously the loss of a husband causes much stress for the widow. Besides experiencing stress with the loss of her husband, the widow will most likely experience additional stress by the sudden life changes which she has little control over, such as: lowered income, poor health, residence change, limitations of social activities, and the like. If there is little or no support from inmediate family, relatives and friends, as the widow experiences these stressful events, she may become overwhelmed with her situation.

The second assumption is, "If the relationship with the husband was satisfactory, widowhood adjustment will be more difficult." It seems plausible that the foundation of a satisfactory relationship usually involves a mutual fulfillment of one anothers' needs, such as emotional support. Since the husband is no longer living to provide that mutual fulfillment of needs, the widow experiences a great loss, thus making her adjustment to widowhood even more difficult. A widow whose needs were not fulfilled and who experienced an unsatisfactory rela- 
tionship, may possibly not experience as difficult a time in her adjusting to the problems of widowhood.

"The older a widow is at the time of her husband's death, the more difficult it will be for her to adjust to widowhood," is our third assumption in this study. We feel this assumption is likely since:

1) older women were raised in an era of being extremely dependent on their husbands, thus preventing them from establishing the necessary skills to be independent, 2) older women, whose children no longer live at home, experience the loss of role of mother and wife, whereas the younger woman still has the role of mother and 3) older women seem to experience more social isolation than younger women. For example, older women have more physical and health problems, which isolates them from social involvement with others. The above statements would seem to indicate that the older woman would have a more difficult time adjusting to widowhood, than the younger woman.

The fourth assumption is, "A decrease in finances, after the husband's death, will increase the problens of widowhood." The woman who experiences a decrease in income is suddenly faced with the burden of finding financial support. For instance, many widows face difficulties when seeking employment, because they have been absent from the work force for many years and lack the necessary skills for today's job market. Other widows are forced to look towards public assistance and find it insufficient to meet their basic needs. In essence, those widows who find themselves in a financial bind, constantly experience frustration and stress, wondering whether or not they will be able to meet their daily living needs. In addition, they will probably experience a change in life style, which further aggravates their adjustment to widowhood. 
"Stress and depression caused by widowhood problems may lead to physical and/or mental health changes of the widow, thus making her adjustment more difficult," is the fifth assumption to be examined in this study. (Refer to assumption one for the definition of "stress.") Depression is defined as symptoms which signify the presence of pathological disturbances or changes in four areas: somatic, psychological, psychomotor and mood. Symptoms in the four areas include: sad (downhearted, low and blue), tearful, exaggeration of symptoms in the morning, difficulty sleeping, loss of appetite, weight loss, decreased libido, constipation, tachycardia, increased and unexplainable fatigue, agitation, retardation, confusion, emptiness, hopelessness, indecisiveness, irritability, dissatisfaction, personal devaluation and suicidal ruminations.

Studies have clearly indicated that physical and/or mental health changes can result from stress and depression. An example, is a study by Holmes and Rahe, as mentioned in Chapter II, "Literature Review." According to many studies, "widows experience a substantially higher rate of mental disorders than the still married."1 In fact, Durkeim is known to have stressed the connection between widowhood and suicide.

The suicides occurring at the crises of widowhood... are really due to domestic anomie resulting from the death of husband or wife. A family catastrophe occurs which affects the survivor. He is not adapted to the new situation in which he finds himself, and accordingly offers less resistance to suicide.?

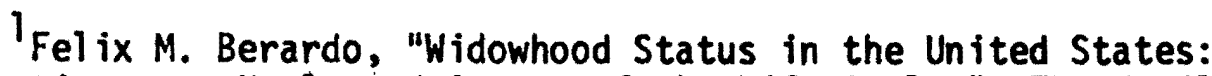
Purspective on a Neglected Aspect of the Life Cycle," The Family Coordinator (July, 1968), p. 196.

2Ibid., p. 196. 
The sixth and final assumption to be examined in this study is "Rigid gender roles in marriage will make widowhood adjustment more difficult." By "rigid gender roles" we mean specific traditional role expectations that the male and female have adopted during their marriage. For the male, some of the roles include: 1) being submissive, 2) being independent, 3) being the breadwinner of the family and 4) being the decision maker. The female roles, on the other hand, include: 1) being submissive, 2) being dependent on the husband for emotional and financial support, 3) raising the children and 4) being a housewife. The widow who has lived within the confines of such rigid roles must suddenly exert herself in the role of a "male" in order to meet her basic needs. This is a difficult task, though, since the role of the traditional male is almost opposite to the role of the traditional female.

\section{Operational Definitions}

Depression, in this study, was measured by Zung's Self-Rating Depression Scale (SDS). (See Appendix A). The SDS is comprised of a list of twenty items, each relating to a specific characteristic of depression. The a im of the SDS is not to classify specific depressive disorders, but rather to measure the intensity of depression an individual exhibits.

The Holmes and Rahe Social Readjustment Rating Scale (SRRS) was utilized to measure stress. (See Appendix B). The SRRS assigns a readjustment value to each life event. "The readjustment value measures the intensity and length of time necessary to accommodate to a life event, regardless of the desirability of the life event."3 Death of a spouse is assigned the highest value of 100 and minor violations of the law are

\footnotetext{
${ }^{3}$ Thomas Holmes and Richard Rahe, "The Social Readjustment Rating Scale," Journal of Psychosomatic Research, 11 (1967), p. 213.
} 
assigned the lowest value of 11 . Further examples are: personal illness or injury--value 53 , retirement--value 45 , change in social activities-value 18, and change in number of family get-together--value 15.

The availability of social network was measured by the widow indicating, during the interview, the amount of phone calls, letters and personal visits she had with members of the immediate family, relatives and friends.

And finally, a self-rating scale was utilized to measure: 1) the widow's satisfaction with the relationship with her husband, 2) dependence on the husband for emotional and economic support and 3) heaith changes of the widow. The widows were asked to respond to questions based on a scale of 1 to 6: 1 strongly agree, 2 moderately agree, 3 agree, 4 disagree, 5 moderately disagree and 6 strongly disagree.

\section{Objectives}

Our purpose was to explore the problems of widowhood, not to test specific hypothesis. It was possible, though, to pick out what appeared to be distinct indications of support for the assumptions made, based on the Zung Self-Rating Depression Scale, Holmes and Rahe Social Readjustment Rating Scale, the widow's self-rating scale of adjustment, as well as information gathered in the interview.

\section{Pilot Study}

A pilot study helped to focus the design of the study. After having contacted the director of a Portland widowhood program (also a funeral director), the researchers received the names of four widows who were willing to be interviewed about their problems in adjusting to widowhood. Open-ended questions were used so that more detailed informa- 
tion could be obtained. (See Appendix $C$ for pilot study questionnaire.) From this pilot study, the final questionnaire was formulated.

\section{Sample}

Originally it was hoped that the sample for this study could be obtained through the Bureau of Vital Statistics, but they were unwilling to release the information. The director of a Portland area widowhood program provided names of widows who served as our sample for this study.

Because this is an exploratory study, the researchers felt it was necessary to examine aifferent situations which widows encounter. Thus, younger and older widows, women widowed for varying lengths of time, widows still having children living at home, widows belonging to the widowhood programs and widows not belonging to the widowhood program, but who used the facilities for her husband's funeral service, were all included in the study.

The director chose twenty women whom he felt would be most willing to participate in this study. Since the widows who belonged to the widowhood program were generally widowed for more than one year, the researchers requested that the names of those widows not belonging to the widowhood program be roughly six months widowed. The intent of this was to get a broader scope of the various problems of widowhood adjustment. The director went back six months in his records and chose the first twenty names of women who were widowed. No other information about these women was available, except for the length of time widowed. Having obtained forty names (twenty widows belonging to the widowhood program and twenty widows not belonging to the widowhood program), we then called these widows, introduced ourselves, explained the purpose 
of our research, and asked them to participate in the study. The first ten widows from each list who were willing to be interviewed became the sample for this study.

\section{MEASUREMENT AND DATA COLLECTION}

It was felt that a home interview using a questionnaire as a schedule guide would be the most effective approach of gathering information about widowhood adjustment. Because it was necessary for the widow to speak candidly and to freely associate her thoughts, it was decided that we would ask the questions, as well as, record the responses. This generally seemed to facilitate in-depth responses and provided us with the opportunity to elicit further responses as necessary. The widows were also asked to record their responses to the Zung Self-Rating Depression Scale and the Holmes and Rahe Social Readjustment Rating Scale during the interview.

Other than the Social Readjustment Rating Scale and the SelfRating Depression Scale, other items included: 1) personal adjustment problems to widowhood, 2) what was helpfur in adjusting to the problems of widowhood, 3) contact with friends and family, 4) relationship with husband, 5) heal th changes, 6) involvement in widowhood programs, 7) what would be helpful to widows in Portland and 8) advice to new widows. (Refer to Appendix 0 for complete questionnaire.)

The demographic information gathered was age of widow, years married, length of time widowed, number of children, number of children living at home, joint income before husband's death, widow's present income, level of education for each spouse and type of occupation for each spouse. 
Before administering the questionnaire, it was again explained to the widows that the purpose of this study would be to find more information about the problems of widowhood. Although their information would be used, they were told that their names would remain annonymous. In addition, the comment was made that through their information the potential existed to help future widows in their adjustment problems.

The questionnaire consisted of twenty questions plus a self-rating depression scale and a social readjustment rating scale. The entire interview averaged one and one-half to two hours per subject.

\section{REPORTING AND UTILIZATION}

The information gathered in this study will be discussed by citing case examples and making inferences based on the assumptions previously mentioned under the heading: "Guidelines (Assumptions) For the Development of the Study."

It is hoped that this study will fill some of the gap that is presently lacking in research about widowhood adjustment. This study does not claim to provide an in-depth report on the problems of widowhood adjustment, but rather provides a general overview about the problems entailed in being a widow. Since there were many relevant factors involved in the problems of widowhood adjustment and it was possible to only touch upon them briefly in this study, there exists a potential to stimulate other researchers to further investigate these areas.

Before examining the assumptions made in this study, let us first review the research that has been conducted in the area of widowhood. 
CHAPTER II

\section{LITERATURE REVIEW}

\section{INTRODUCTORY REMARKS AND SCOPE OF WIDOWHOOD PROBLEMS}

In the past fifty years, the U.S. has seen a continuous and substantial rise in the number of widows. In 1970, there were approximately 12 million widowed persons in this country, of whom 10 million or $85 \%$ were women. Approximately $25 \%$ of the 12 million were less than 65 years of age. Those widows whose husbands died of natural causes, had been widowed for an average of 18.5 years. These statistics show that widowhood is not merely a problem of the elderly; it involves a considerable proportion of the people in this country and may represent a lengthy period in their lives. 1 It is predicted that by the year 2000 there will be 30 million widowed persons in the U.S. ${ }^{2}$

During the past several decades, the widowed female has been outdistancing her male counterpart by a continually widening margin. By 1970, the ratio of widows to widowers had risen to more than 4 to 1 . This growing excess of widows in the U.S. is due to three factors. First, the mortality rate among women is lower than among men, consequently larger numbers of women reach an older age. Second, wives are usually younger than husbands and even without sex differences in mor-

IRuby Banks Abrahams, "Mutual Help for the Widowed," Social Work (September, 1972), pp. 51-61.

: 2 Vancouvering, Virginia A., Workshop on Widowhood Adjustment in Seattle, Wa. (Spring, 1976). 
tality have a greater likel ihood of outliving their husbands. Third, the remarriage rates among the widowed are higher for men than for women. 3

Thus, widowhood is becoming a major phenomenon of American society. Yet this inevitable and universal phase of life is little studied. In recent efforts to give attention to the latter stages of life, social scientists have seemed to concentrate on the problems of the aged population. Specifically, data on the aged are often not distinguished with respect to widowhood status; consequently exact information concerning the widowed becomes difficult to ascertain. Moreover in most recent research, differences in levels of functioning as well as differences in backgrounds and experiences are ignored; social class and cultural values are typicaliy not considered; and many other important socioeconomic variables are put into the all-inclusive category of "the aged". 4 The fact that a substantial majority of widows in the U.S. does not fall within the usual definitions of the aged population is frequently ignored. For example, about $1 / 5$ of the new widows each year are under 45 years of age and their situation is in many respects different from the widowed of later ages. ${ }^{5}$ And in this same vein, the divorced, separated and widowed are frequently combined into a single statistical category. This further obscures specific data with respect to widowhood. 6

Another major reason for the lack of research about widowhood

${ }^{3}$ Fel ix M. Berardo, "Widowhood Status in the United States: Perspective on a Neglected Aspect of the Family Life Cycle," The Family Coordinator (July, 1968), pp. 191-203.

${ }^{4}$ Ibid.

5 Ibid.

$6_{\text {Ibid. }}$ 
centers around cultural taboos associated with the phenomena of death. Such taboos become engrained at a relatively early age and the influence seems to persist throughout the entire life cycle. Krupp and $\mathrm{K} T$ igfield have noted that many factors in the U.S. operate to prevent a direct confrontation with the reality of death:

Much in our American cul ture conspires to remove death from our minds and even our feelings. In television, the movies, and other expressions of our mores, emphas is is on the preservation of youth and the denial of aging. Death, though threatening and difficult to handle, is made remote. Social Security and the proliferation of nursing homes have facilitated the removal of many elderly and severely sick persons from the family circle... Death has become for us foreboding, frightening, repugnant and mysterious.'

Finally, it should be noted that with medical and technological advances, death is increasingly becoming an experience of the aged. They are usually retired from work, free of parental obligations and often absent or outside of the mainstreams of family life. Death of the elderly seems to have become less relevant as they are to the functional workings of contemporary society. Death and widowhood simply do not compel much attention. ${ }^{8}$

In regard to the above, Abrahams points out that in all non-Western societies, structured ritualized roles are offered to the widowed. These roles give security and help the person adjust to loss of a spouse. Yet in the U.S., widowed persons have little structure or support to guide them -- there is no defined role and no expected behavior patterns for the widowed. ${ }^{9}$

${ }^{7}$ Ibid.

8 Robert Fulton, "Death, Grief, and Social Recuperation," Omega 1 (1970), pp. 23-28.

${ }^{9}$ Abrahams, op. cit. 
In a study of services available to widows, silverman concluded that after the initial phase of grief, there are few caregivers for the widowed. ${ }^{10}$ Lopata said that the majority of widows she studied, felt that no one helped them during the period of grief and subsequent readjustment. After the funeral, family members go their own ways, the funeral director and clergy who helped with the initial arrangements rarely carry on with caregiving and the widow is left alone in totally new life circumstances for which she has little or no preparation to deal with. 11

\section{GRIEF}

Grief is a normal process and should not be treated as a psychological problem. The direction of the grief reaction and the manner in which a person finally adjustş to his loss depends upon the success of the grief work, i.e. freeing the widow from the emotional bondage to her husband and the formation of new relationships. A normal grief reaction may last anywhere from 6 months to 3 years and after that point, it is considered to be detrimental to her functioning effectively. When someone avoids the pain and emotion associated with grief, a morbid grief reaction may appear in the future. ${ }^{12}$

\section{Stages of Grief}

1. The first stage is that of shock and disbelief which occurs upon learning of the spouse's death. Some people go through this stage

${ }^{10}$ Ibid.

11 Ibid.

12 Fulton, op. cit. 
of shock and are able to express their feelings while others feel "numb". The numbness refers to the person being cushioned from the act of pain. During this stage of shock, the person is unable to accept the loss of a mate. Shock usually continues through the funeral ${ }^{13}$

2. Emotional release -- Acute episodic pain -- outbursts of crying. If a person does not cry during this stage, it may be expressed in other forms. ${ }^{14}$

3. Physical and emotional reactions

a. increase in accidents

b. somatic symptóms

1. tightness in throat

2. choking with shortness of breath

3. need for sighing

4. empty hollow feel

5. lack of muscular power

6. problem with digestive system
a. ulcers
b. colitis

c. slight sense of unreality

d. feeling of emotional distance from people

e. sometimes people appear shadowy or very smal1 15

4. Impact -- During the stage of impact, three quarters of the

13 Murray C. Parkes, "Effects of Bereavement on Physical and Mental Health - A Study of the Medical Records of Widows," British Medical Journal 2 (1964), pp. 1-15.

14 Ibid.

15 Ibid. 
widows experience recoil -- looking back to the way it was with their husband. This experience of recoil is expressed by means of:

a. pain

b. anger at her husband for leaving her

c. guilt as a means of punishing herself for being angry at her husband for dying or for leaving any unf in ished business such as doing things you could have done or should have done, but did not.

d. confusion and preoccupation with the deceased husband -the widow finds it very difficult to shift her thoughts away from the deceased husband.

\section{e. restlessness}

f. identification - the widow searches and identifies with the things her husband liked such as renewing his magazine subscriptions and making foods he liked.

g. depression - the widow feels like there is nothing to live for and nothing seems worthwhile. Thoughts of suicide may be prevalent here.

h. hostile reactions - the widow responds to others with irritability and anger. These feel ings are of surprise to the widow and makes her feel like she is going insane. alone forever. 96

5. Road to Recovery - Three fourths of the widows make it to this stage. The road to recovery includes:

a. slow recovery

b. reorganization

c. reassessment

d. setting new goals

e. letting go of the past and having life energy free for the present and the future.

f. developing new life patterns 17

${ }^{16}$ Ibid.

17 Ibid. 
5a. Morbid Grief Reaction - One fourth of the widows rema in in this stage.
a. resignation
b. chronic depression
c. delayed grief
d. hypochondria
e. isolation 18

6. Outcome - The successful work of mourning takes a year or more. The clearest evidence of successful mourning is the ability to remember comfortably and realistically both the pleasures and disappointments of the lost relationship. 19

Many factors influence the outcome of grieving process. A major one is the importance of the deceased as a source of support. The more dependent the relationship, the more difficult it will be to resolve the loss. The degree of ambivalence toward the deceased is another. When persistent, unresolved hostile feelings persist, guilt can interfere with the work of mourning. The age of the deceased is another factor. The death of a relatively younger husband may present more difficulties than that of an older husband. The widow with few meaningful relationships, has a more difficult time effecting the detachment from her dependence upon her deceased husband. The degree of preparation for the loss is a factor in that the death of an aged or incurably sick person, some grief work may go on before the death. Also the physical and mental health of the mourner at the time of the loss is a determinant of

18 Ibid.

19 George L. Engel, "Grief and Grieving," American Journal of Nursing 64 (September, 1964), pp. 93-98. 
the coping capacities of the widow. 20

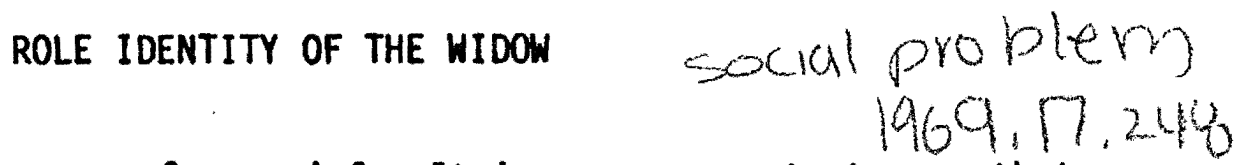

One does not recover from grief. It is more accurate to say that the woman realizes she must make an accommodation or adjustment from the role of wife to the role of widow. The direction this role change takes is related to how much of the role of wife permeated the lives of these women. 21

The woman who works has a good part of her identity invested in her job role. Her marital status may be irrelevant to this situation. Even if she still maintains her image of herself as a wife, this does not create conflict for her at work and she can still function well there. However, the fact that a woman can still identify herself witt an intact role may postpone a confrontation with her new reality at home. Some of these women find that 6 months or a year later they begin to feel lonely and mourn in a way they had not done before. ${ }^{22}$

$X$ A woman whose entire self was invested in being a wife and mother will begin her career as a widow very quickly. Her life is suddenly empty and she has no meaningful role available to her, no one to share her daily life with. She has lost the opportunity for an intimate social and emotional relationship that for most people comes only in marriage. Unlike the working woman who has at least one major role, these women have to develop new roles for themselves. ${ }^{23}$

20 Ibid.

21 Phyll is Silverman, "Widowhood and Preventive Intervention, " $X$ The Family Coordinator (January, 1972), pp. 95-102.

22 Ibid.

23 Ibid. 
There are other roles available to the new widow. Sometimes her role as mother, sister, or daughter was more important than that of wife. Even with her husband's death, these roles do not change and she may continue with these as before. In an older population a woman is seldom the first to be widowed in her group and widowed friends provide her with a social network. However this may not be acceptable to her since she may not be able "to accept herself as one of them yet."24

So the status transition the individual undergoes to become a widow can be described as starting when the new widow realizes this word applies to her. She has accepted the reality of her situation - her husband is dead forever, she is lonely, and is in much pain - but she may not be ready to act upon her recognition of this reality. Grief can really be seen as an inner struggle not to assume to widow role, to deny the reality of the loss and to recapture and live in the past. When this fails, the widow can recover and her career as a widow begins. She will have to live with the "widow" status until either she remarries or dies. It is here an educational process must begin for she finds herself in a social category long known to mankind but at the same time completely ignored by Western society. She has little social or religious tradition to guide her. 25

PROBLEMS OF WIDOWHOOD

Problems the widow must deal with are numerous. However interestingly enough, attention to the problems a widow faces is seldom given much recognition in widowhood research. If one does come across any

${ }^{24}$ Ibid.

24 Ibid. 
references to widowhood problems, it is generally of a statistical nature -- little if any description of the problem accompanies the statistics. Throughout the literature search, the only problems of widowhood mentioned were loneliness, unfriendly friends, feeling like a 5 th wheel, finances, and employment.

\section{Lonel iness}

Though the problems each widow experiences varies, there seems to be one common difficulty among them -- that of loneliness. Lopata, in her studies about widowhoad devotes much of her work to the problem of loneliness. Finding that loneliness covered a broad range of different experiences, she sought to categorize different aspects of lonel iness. She found that widows were lonely for their husbands as: 1) a total individual, a unique person; 2) an object of love; 3) the person making them an object of love; 4) a partner or companion in activities; 5) an escort in couple-companionate relationships; 6) someone with whom to talk; 7) a partner in a division of labor within the home or tying her to the economic and social world; 8) someone around whom work and time are organized; and 9) someone around the house. 26

The most lonely and frustrated widows seemed to be the ones who expected someone to take over the relational or task duties previously performed by the husband, and who are without such help. The least frustrated widows appeared to be those who had some sort of social network available to them or relationships developed since the husband's death. The availability of a social network seemed to allow the widow to redistribute some of the rights, duties and sentiments previously

26 Helena 2. Lopata, Widowhood in an American City (Boston: Schenkman Publ ishing Co., 1973), p. 149 . 
focused on the husband and/or served as more than substitutes for their past life styles. 27

Unfriendly Friends

Many widows feel a strain with friends in the early stages of widowhood. Widows often report that friends avoided them, felt uncomfortable about what to say and feared the widows would express their grief and despair, and loneliness.

\section{Feel ing Like A Fifth Wheel}

This problem was prevalent among women who had shared many couple friendships with their husbands. Younger widows often seem to feel that their women friends now regard them as threats out to get their husbands as sexual partners or mates. Other widows say they feel uncomfortable going places without male escorts, so they do not go.

\section{Finances}

Because the majority of widows are aged, their economic circumstances are usually below average. A special survey of widows 55 years of age or older showed that about $2 / 3$ of the husband's total assets were worth less than $\$ 10,000 ; 41 \%$ of the husbands left assets worth less than $\$ 5,000$. Census data on the aged shows that median income of the widowed as a group is less than $\$ 1,200$ per year. 28

It is true that life insurance has become a principal defense against the insecurity and risk of widowhood in our society. Nevertheless, it has been the experience of investment bankers and the like that 27 Ibid.

28Berardo, op. cit. 
few female survivors are capable of handling the economic responsibilities brought about by the husband's death because they know little about matters of real estate, mortgages, contracts, stocks, bonds, and property matters. 29

Widowhood and Employment

Due to the serious economic problems many widows encounter after their husband's death, many find it essential to seek employment. This is especially true if the widow has dependent children at home. While women entering widowhood at older ages are not as likely to have dependent children in the home, they are often faced with economic problems since Social Security benefits only provide for minimum necessities. The obstacles these women must overcome to ga in employment are difficult. Typically these women have been absent from the labor market for years and are at a severe disadvantage with respect to occupational and educational demands of current employment. In addition they are often confronted with pervasive and subtle discrimination by employers who do not want to hire older women. Since the majority of widows, particularly older ones, are unable to support themselves, many are partly or wholly dependent on the assistance of relatives and public funds -. and still many widows live in economic circumstances that are far from satisfactory. 30

Widows who have obtained employment are heavily concentrated in the low paying jobs. Less than one-tenth of all widows are employed in technical or professional occupations. In any case, research indicates

$$
{ }^{29} \text { Ibid. }
$$


that playing a role in the productive economy is predictive of a favorable adaptation to widowhood. The acts of preparing for work carrying out one's tasks and returning home are viewed as being intimately connected to feelings of personal worth, self-esteem and significance in life. 31

\section{PHYSICAL AND MENTAL HEALTH OF THE WIDOW}

In considering the topic of physical and mental health of the widow, it is helpful to look at the Social Readjustment Rating Scale developed by Holmes and Rahe. This scale was based upon previous research that showed changes in ongoing life patterns are significantly associated with times of illness onset. Similiarly the relationship of life stress, emotional stress, object loss and illness onset has been shown. Items on the Social Readjustment Rating Scale pertain to such topics as the nuclear family, occupation, economics, group and peer relationships, recreational activities and education. The common tie among all events on the Scale is that all called for some adaptive or coping behavior by the individual. On the scale, different transitional events are assigned a value from 11 to 100, the higher values being indicative of more stress. Death of a spouse is assigned a value of 100 , with divorce being second with 73 points. 32

Recent research seems to confirm that widowhood presents serious personal difficulties and mental health problems. Empirical research has demonstrated that the widowed have higher death rates, a greater

31 Ibid.

32 Thomas Holmes and Richard Rahe, "The Social Readjustment Rating Scale," Journal of Psychosomatic Research, 11 (1967) pp. 213-218. 
incidence of mental disorders and a higher suicide rate than their married counterparts. 33

There also has been research conducted giving statistical confirmation to the hypothesis that death in a family produces an increased post-bereavement mortality rate among close relatives, with the greatest increase occurring among the surviving spouse. At present little is known about the primary link between bereavenent and mortality. Personal ity factors, social isolation, age (old people withstand bereavement better than young), and the nature and the magnitude of the loss all seem to be important factors. When the bereaved person is supported by a united and affectionate family, when there is something left to live for, when the person has been adequately prepared for the loss, there will seldom be much need for professional help. However, when the bereaved person is left alone in a seemingly hostile world, when the future is black and the loss has not been prepared for, help may be needed. 34

\section{MODELS AND EXAMPLES OF SERVICE PROGRAMS AVAILABLE FOR WIDOWED}

There are three major models of service programs available for widows. All three models operate on the premise that the goal of helping the widow is not to abolish grief. Rather it is to help the widow adjust to life as a single person and to be able to live with grief. ${ }^{35}$

$33_{\text {Berardo, op. cit. }}$

34 Ibid.

${ }^{35} \mathrm{~S}$. Donna Lind and Donna Jette, Handbook on Widowhood Adjustment, July 1975, p. 8. 
Widow to Widow Programs

This program was developed in response to the finding that most caregivers who would normally be available to the widow were fearful of a bereaved individual, attempting to shut off her mourning prematurely and then withdrew while there was still a great need. 36 This program views widowhood as a natural process and does not use professionals who might connote a psychological problem. Widows themselves are used as outreach workers. These widow aides contact new or recently widowed women and try to establish a relationship with them. 37

One such widow to widow program was using widow aides as outreach workers and was sponsored by the Department of Psychiatry at Harvard Medical School and had been in operation for three years. In this project, the target population was the young widowed, a group of people who have a high risk of developing serious emotional illness. The philosophy utilized by the widow aides in this project is discussed below. 38

The widow aides believe that a first step of recovery for the widow is the need of the widow to change from seeing herself as married to thinking of herself as widowed. Here the widow must learn to make decisions independently without the help of her husband. She needs to learn to be alone. Finally, widows face a growing need to make friends and be out with people. 39

As for decision-making, in the early stages of widowhood, the aide

${ }^{36}$ Silverman, op. cit.

37Phyllis Silverman, "The Widow as a Caregiver in a Program of Preventive Intervention with Other Widows," Mental Hygiene, 54 (October, 1970), pp. 540-547.

38 Ibid.

39 Ibid. 
will give direct advice when the widow is very confused and needs direction. In the latter phase, the aide usually gives encouragement, ideas, support and emphasizes the need for the widow to act for herself. 40

To cope with loneliness, the aide helps by being available, at least by phone. Some widows try to avoid loneliness by never being home while others put all their energy in to taking care of their children. The aides try to help the widow by finding a middle of the road. ${ }^{41}$ To help widows make new friends, aides help widows find other groups of "single" people where they find common interests and/or may try to get these widows to reach out to other widows in their area who have refused to see the aide or a physically disabled. ${ }^{42}$

Through the widow to widow programs, it is hoped that the recipients will move to becoming the providers. As a provider of services, the widow develops a greater sense of independence and self-worth. As far as this goes, Harvard's sponsored widow to widow program is able to achieve this, it should be able to accomplish its goal of preventing emotional breakdown in the new widow. ${ }^{43}$

\section{Widowed Service Line}

A second model of service program for widows is called a Widowed Service Line (WSL). This is a hotl ine where volunteer widows and widowers answer phones.

One such WSL was established and carried on for three years as a

40 Ibid.

${ }^{4 l}$ Ibid.

42 Ibid.

43 Ibid. 
demonstration project in Boston. Information was gathered from a total of 570 calls. Calls were classed according to major problems: 1) lonely - wants to meet people, $37 \%$; 2) $20 \%$ were lonely in the sense that they wanted a listener; 3) $22 \%$ wanted specific information; 4) $16 \%$ wanted to know more about the WSL; 5) $5 \%$ wanted to volunteer for the WSL. ${ }^{44}$

It was found that widows who called within the first year of bereavement usually needed an understanding listener. From the second to sixth year of bereavement the caller was in the recovery stage in which the stress passed and the individual has developed new functioning roles and is once again oriented to past, present, and future. At this point, the individual was reentering the social system and was looking for new roles and was interested in building a new network of social relationships. ${ }^{45}$

The younger widows were more interested in seeking new social relationships than older ones. The older widows looked more for a listener and were more likely to need help with specific problems, other than social ones. ${ }^{46}$

It was found that widowed callers under 40 years old were similar to those over 60 in that their presenting problems were other than social. Eighty-three percent of the widows under 40 had children living at home and called mainly due to problems concerning single parenthood. It also appeared that widows while raising children need less help than other widows making new friends. This may be due to the relationship with

${ }^{44}$ Abrahams, op. cit.

45 Ibid.

46 Ibid. 
children being emotionally sustaining and/or children's activities may bring the parent into social networks. ${ }^{47}$

When these 570 widowed people were asked who has helped most with grief and subsequent readjustment problems, $46 \%$ said relatives, $21 \%$ said no one heiped them, $22 \%$ replied friends, $4 \%$ said other professionals, $4 \%$ received help from clubs and groups and $3 \%$ felt clergy very helpful. ${ }^{48}$

These widows were also asked about their social life. Sixty-nine percent of these people felt they were isolated, $22 \%$ reported they had an active social 1 ife while $17 \%$ said that bereavement was too recent for social activities. ${ }^{49}$

Most callers contacted WSL on their own initiative, but a relative or friend called for $11 \%$ of them. Often these concerned relatives or friends felt unable to give the widowed person the help needed. Some persons referred in this way had serious psychological difficulties; some were in a state of extreme depression, or even at the point of threatening suicide. These disturbed callers were referred to volunteers who had four or five years of experience and had developed a high skill level. The aides followed through with all seriously disturbed callers, maintaining contact until the crisis was passed. Often the aides persuaded such callers to seek professional help. Many telephone conversations with these callers lasted from one to three hours, often late at night. The aides were always available for emergency calls. They intensively followed through on most of these callers for two to 47 Ibid.
${ }^{48}$ Ibid.
${ }^{49}$ Ibid. 
three months. 50

\section{Lecture Format of Widow Programs}

The final model of widow service programs is the Lecture Format. (This is the model that is used in Portland, Oregon). The purpose of the widow to widow program utilizing the lecture format is to jointly serve as a therapeutic function and social function. Sponsors of these programs have regular meetings for widows and widowers with guest speakers on relevant topics. One month the meeting deals with psychological issues dealing. with problems of widowhood adjustment and the next month with more concrete issues such as finances, insurance, deeds... During these lectures, group discussion is always encouraged. 51

The second half of the meetings are a social gathering in which coffee and cookies are served. This portion of the program is just as important as the first half in that it provides the widow the opportunity to become involved with others and helps them to establish new social relations.

The lecture format model is good for developing a feeling of group membership and for reassuring the widow that her problems are shared by others. It also creates a situation where those attending may develop an informal network of support and friendship for one another.

As should be evident from this literature review, there are many areas in which research about widowhood is severely lacking. Perhaps the problems of widowhood, as briefly discussed in this review, best exemplifies this neglect in research. In the next chapters, an in-depth look will be taken at this much neglected aspect of widowhood.

${ }^{50}$ Ibid.

$51_{\text {Lind }}$ and Jette, op. cit. 


\section{CHAPTER III}

\section{PROBLEMS OF WIDOWHOOD}

It is our impression that widowhood is so common--affecting three out of four women--that it must be considered as a natural stage in the life cycle. Encompassed in this stage is the transition from the role of wife to the role of being a widow. This is a difficult task particularly in a society where the role of widow is undefined. One very important aspect involved in completing this transition is the widow's acceptance of herself as a single person. This is sometimes postponed, though, when the widow experiences varying degrees of role ambiguity associated with vague and contradictory expectations for appropriate behavior. Such expectations include: 1) When to terminate the mourning period. It is expected that the widow mourns, but if her mourning is not long enough or is too long, she becomes stigmatized. 2) When is it "appropriate" to date again, and 3) How long should the widow wait before she considers marriage? If the widow marries too early, others may question the relationship she had with her husband.

Thus, these role ambiguities force the widow to search for her identity. She basically has three options from which she may choose to seek her identity. She may return to the same activities she had while her husband was living, depending on whether or not the presence of a male is required. Or, the widow may choose a completely new role and make a new set of friends. Finally, she may stay in isolation and perpetuate the grieving process. The option which the widow chooses, will 
influence the direction of the development of her self-identity.

One factor plays an eninent role in adjustment to widowhood: our society's attitude toward death. The end result is avoidance of the subject of death, since one cannot escape from it. This avoidance is illustrated by: 1) society shielding children from death, 2) the constance use of euphemisms, such as: the person has "passed on," "passed away" or "gone to heaven" and 3) lack of contact with the dying person or the grieving family. It is even easier to avoid death because there are professionals, hospitals and nursing homes which now assume the roles which the family once had during the pioneer days. Death may occur outside the home, further separating the living from the process of death.

Generally, most people avoid close contact with the dying husband or the grieving widow and her family because they feel uncomfortable with the subject of death. Part of this feeling uncomfortable is not knowing what to say, fear that the widow will express grief and also, a great fear that one day, "I" might also be in the same situation of becoming a widow. What the friends and family don't realize is that their lack of contact with the widow only adds to the widow's grieving process. The widow is already feel ing one loss and to add the loss of friends and family, especially during a time when she needs their support most, makes her adjustment even more difficult.

If we are brought up in a society where death is a taboo subject, how can we understand or help the widow adjust to the problems of widowhood? There is no doubt that this society needs to become comfortable with the subject of death by reading about and openly discussing it. It is because of this need for re-educating the public that this explora- 
tion of the problems of widowhood was begun.

Our respondents were asked to indicate the three most difficult adjustment problems they have had to face since becoming a widow. The widows indicated overwhelmingly that lonel iness was their most difficult adjustment problem. In addition to lonel iness, the other major adjustment problems (most mentioned to least mentioned) included: having no one around to fix things, decision making, finances, feeling uncomfortable in a couple-oriented society, going places where male escorts are expected, abandonment of friends and family and parenting alone.

Widows concerned about lonel iness referred to a lack of companionship as a "void" or "emptiness." One widow stated, "I'm used to going home and having somebody there." The widows gave impressions of having no one to turn to, no one to do anything for, no one to do things with, no one to love them and having no one to love. They expressed feelings of not knowing where to turn, disbelief that the husband is suddenly gone and questioning whether life is worth living. One widow described lonel iness as "Shock... You can't bel ieve that you're alone. Being blue, upset and weeping for 3 to 6 months. Finally you decide that you can't die because someone else died." So, it seems, that a sense of a lack of companionship is the most prevalent experience of lonel iness.

However, other experiences of lonel iness were also expressed. A widow finding eating alone as a difficult problem said, "I don't sit at the table, I eat on the davenport: Not once have I sat at the table when I've been alone." One widow finding sleeping alone as a problem stated, "The first five minutes before we'd go to bed we'd kiss and talk. 
I miss his stomach." Another aspect of loneliness mentioned was missing mutual love. This was described by a widow in her statement, "You miss the love you had--it's the little things you do for one another." So it is evident that loneliness is experienced in different ways. Following loneliness, the most frequent response concerning the problems of widowhood was not having someone around to fix things. This was extremely evident when we interviewed one woman. Upon entering the widow's home, she immediately began to express her frustration with the condition of the house. She suggested that we have the interview outside, which meant that we had to walk through the living-room and the kitchen to get there. As we walked through the kitchen she suddenly stopped and showed us those things that needed to be fixed--which her husband would have taken care of. In addition, she began to elaborate on all the other things that needed fixing in the house and how she was unable to repair them herself. She kept referring back to what a handyman her husband had been. When we reached the outside area where the interview was going to take place, she immediately took us around the garden area. She then pointed out the "poor condition" of the plants, shrubbery and grass, al though we felt that the yard looked fine. The widow said that the yard work was her husband's hobby and obviously indicated her frustration with not being able to maintain the garden area as her husband had. As she was talking, she became tearful and more frustrated with the whole situation.

Having no one around to fix things is a definite problem for many widows. A good part of this difficulty stems from our culture in which we have defined gender oriented tasks. Being a handyman is a male task. Now the widow finds herself as a single person and faced with the deci- 
sion of learning to fix things herself or to rely on other males to fill the gap.

Closely tied in with the above, the third most frequently mentioned adjustment problem was indecisiveness. Decision making is difficult for the new widow who is in the grieving process. Shock, disbelief, numbness, loneliness and fear are feel ings which suddenly envelop the widow. The intensity of these feelings make it difficult for her to put almost anything in its proper perspective. Decisions of what meal to fix, what items to buy at the store, what clothes to wear are extremely difficult to make, let alone the decisions of whether to sell. the house or give away the husband's personal belongings. Comments expressed by widows were: 1) "you suddenly have to make all your own decisions and there's no one to talk them over with. You don't know if you're doing the right thing or not," 2) "making decisions by myself, even small decisions are hard to make" and 3) "making decisions was a difficult adjustment. My husband did everything for 23 years. I was really spoiled." From talking with these widows, it appeared that they had always had someone around with whom to discuss matters. Now that the widow is all alone, she is suddenly faced with forced independence. All decisions are hers alone to make --

No one is right there to talk things over with, no one to give you support once a decision. is made. There's an overwhelming feeling of what to do now.

Almost all the widows interviewed advised that no major decisions should be made within the first year.

- In addition to loneliness, having no one around to fix things and decision making, finances presented another major problem for many 
widows. Financial security is a major factor in how one adjusts to widowhood, therefore, it will be discussed more fully in a later chapter.

The most significant problem with finances is, of course, the loss of income, which has many ramifications for the new widow. Some of these ramifications are expressed by a widow who stated:

It's catastrophic financially. His pension did not go to me. There was a loss of double salary. Family illness was a problem and took all our savings. He was $i 11$ for four years and I had to be with him, so I couldn't work.

It appears that the consequences of loss of income revolve around whether the widow is able to maintain her status-quo--economically and/or socially. For instance, many widows are unable to pay their bills, are forced to make a change of residence, are unable to develop new interests or maintain old ones and feel uncomfortable with their friends, because they are unable to maintain the same life styles they previously had had with them.

Another problem which seems to exacerbate the problems of widowhood adjustment is the feeling of being uncomfortable in a coupleoriented society. Widows have frequently used the phrase "feel ing like a 5th wheel" to describe their situation. This is well expressed by the widow who was forced to build a different social life as the result of feeling like a "5th wheel."

If you had companionship with married couples, you don't feel comfortable with them anymore, because you're the odd person. Therefore, you tend to be mostly with women in groups.

Another widow stated, "You no longer fit into the natural niche of "Mr. and Mrs."

Two other factors affect this feeling of being uncomfortable in a 
couple-oriented society. The first deals with the widow's own concern that her married women friends might consider her a threat, in terms of possibly taking their husbands away. The second is the widows concern about going places alone. This difficulty is aggravated when the widow goes places where male escorts are expected (bars, restaurants, etc.)

Besides feeling uncomfortable in a couple-oriented society, some of the widows interviewed seemed to feel that abandonment by friends and family was also an adjustment problem of widowhood. One widow exclaimed:

People deserted me. People. who I thought would stay with me all my life, deserted me. His family deserted me and we were real close.

Abandonment to the widows seemed to mean: 1) lack of attention which they so desperately needed at the time of their husband's death, 2) not having friends or family around on which to vent their enotions, 3) friends felt uncomfortable discussing the subject of death and, as a result, maintained little or no contact with the widow and 4) friends also maintained little or no contact with the widow because the widow served as a reminder that their spouse might also die. The onset of widowhood is a time when one needs emotional support, but due to the factors mentioned above, widows often felt totally abandoned. One widow puts it this way:

There is no one to listen to you or give you attention. No one realized what you're going through. Family, friends don't give me enough attention. You want to talk about it, but there's no one to listen. I wanted someone to spend nights with me at the beginning. Everyone is afraid to open up. You want them to understand, believe and call on you. There are no phone calls and you want to talk about it. 
As was mentioned earlier in this chapter, abandonment by friends and family due to the uneasiness with death, is one of the major problems which hopefully can be overcome by public awareness of the adjustment problems faced by the widow.

Another widowhood adjustment problem which should not be neglected is that of parenting alone. This problem mainly existed for the younger widows. Those women who mentioned this as a major difficulty feared the responsibility of raising their children alone. Previously, the widow's husband helped make joint decisions in child rearing, but now she is faced with being all alone in making decisions and carrying them through. One widow with two children living at home talked about her dependency on her husband to make many of the child rearing decisions. Now that all the decisions were falling on her shoulders, she expressed the fear of being solely responsible for her children's future. This is a heavy burden the widow suddenly has to face.

Concominent with the difficult adjustment problems of widowhood mentioned above, is the widow's search for her identity. She has been in the role of wife for a long time and now is forced by circumstances to give up this role and enter the role of widow. This role transition cannot be accomplished easily, since this society has neglected to include widowhood as a continuing part of the life cycle. 


\section{CULTURAL ROLES}

A widow feels empty and incomplete because, like most women, she gained her identity through marriage. And when her husband died, there she was. A widow. Empty. Without her husband to validate her existence. Without an identity of her own...It is sad that the progression of grief is so much more difficult for widows than for widowers. But there is a reason for it. Men do not think of themselves primarily as husbands and fathers. They have been enoouraged to develop their full potential as unique human beings. So when a man becomes a widower it is truly a heartbreaking blow, but it does not spell an end to his whole way of life. He still has his identity through work, through play, through living... The lesson is that women must learn to be more self sufficient, to live alone. Because the majority of women will have to eventually....

The above is a brief excerpt from an autobiographic book, Widow, by Lynn Caine. It seems a fitting and appropriate introduction to a chapter which will explore how culture influences our sex roles, our marital roles and finally how these rigid marital roles ultimately makes the widow's adjustment more difficult.

Think a moment about the extent our culture influences and shapes our gender roles. At birth it has been found that the responses of parents and other adults to newborn infants vary according to the sex of the child. Girls tend to receive fondling and petting kinds of attention while boys are jostled and teased. Parents tend to talk more to male children, spend more time with them, buy them more toys, and allow them more freedom than female children who are far more protected, restricted and controlled in their daily activities. Subtiy in eariy 
childhood, the stage is being set to channel females into dependent roles while males are channeled into independent roles.

When it comes time to enter school, these gender role differences are further exacerbated. In Kindergarten, giris are encouraged to engage in quiet "ladylike" activities like playing with dolls, singing, and painting. On the other hand, boys are encouraged to engage in actionoriented endeavors like playing with soldiers, trucks and building blocks. The majority of stories in books in elementary schools focus on the achievements of great male heros. Seldom, if ever, does one come across a story centering around a woman's achievements.

In junior high and high school, males and females receive further preparation for their "proper" gender roles. Girls take home economics courses which offer advice on hair styling, dress, cooking and etiquette anticipatory activities for their future roles as wives and mothers. Boys take shop courses where they learn instrumental skills that they will need in the future.

Examples of how our culture shapes males and females into rigid gender roles during childhood and adolescence are endless. In general, it can be said that females are taught to be dependent people while males are taught to be independent people via cultural achievement demands and high personal expectations.

It should come of little surprise that when it comes time for marriage, there is seldom a change seen in these rigid gender roles. The "independent" man becomes the breadwinner; he must go out and earn a living to provide for his wife and family. The "dependent" woman's role usually centers around the home; she is to look pretty, keep the home clean, raise the uids, and be the "woman behind the man." 
This was the typical story for many of the women interviewed for this study and it was felt that we could safely guess that it also applied to a majority of women in this country. At one point in the interview, we questioned each widow as to her economic dependence upon the husband. One widow said, "Man is the head of the home. We set it up that way and had no problems with women's lib." Another widow stated, "I was dependent on him for everything. He made up his mind that I'd stay in the home and he'd go out and work." It should be pointed out that some of the widows who were interviewed did hold jobs while the husband was still alive. But most of these women worked at what they described as "fun jobs" which served to supplement the husband's income to provide for the extra luxuries of life. One widow who had worked made a comment which stands out in our minds. She said, "I had been in the semi-professional work force all of my years. My earnings were more than his. I worked shorter hours so I'd earn less to build him up." In this example, it is pretty plain to see that this woman wanted to keep her husband's male ego up. After all, man is supposed to be the breadwinner and woman does not want to infringe too far upon his territory.

In addition to dependence upon the husband for economic support, we inquired about dependency upon the husband for emotional support. Although no definite conclusions can be drawn, it did appear that the very same women who were dependent upon the husband for economic support were also highly dependent upon the husband for emotional support. One widow when speaking about the emotional support her husband provided her said, "We talked together. He didn't want me to worry about anything, even when he was sick." Another widow said, "You'd better 
believe it. I was dependent on him for everything." A third widow responded, "He was my backbone. I feel lost... I'm not like I used to be. Now I'm weak. I'm not strong like before."

So it seems rather evident that many couples still appear to abide by the traditional rigid gender roles, at least within our sample. The woman is primarily mother and wife with her role centering around the home, children, and husband. The man is the breadwinner and provider for the family. The researchers wonder if adherence to the rigid gender roles (i.e. the woman's economic and emotional dependency upon the man) could have some connection with satisfaction of the marital relationship. At one point in the interview the statement, "I was satisfied with my relationship with my husband" was evaluated by the widows according to a self-rating scale. An overwhelming majority, $90 \%$ of the widows, strongly agreed or moderately agreed with this statement. Typical comments were "We had a real good life together" and "He was a very special person. I doubt if anyone could replace him". Only two widows, one whose husband had been an alcohol ic and one whose husband had been a schizophrenic, showed dissatisfaction with the marital relationship. It is interesting to note that both of these "dissatisfied" widows had to perform the "male gender duties" of being the economic provider and the emotional support for the marital pair. Perhaps satisfaction with the marital relationship is related to the adherence of the male/female gender roles. This is an hypothes is which needs further study.

Not surprisingly, it seems that the widows in our sample, who were highly dependent upon their husbands, had an extremely difficult time in adjusting to widowhood. Like most widows, lonel iness seemed to be their biggest problem. But the loneliness of these widows seemed deeper 
and more pervasive than the loneliness of other widows. Many of these women had been totally dependent on their husbands for everything and never had to be self directing and make their own decisions. Some of these women did not know how to balance a checkbook, never even partook in a joint decision, never went anywhere alone... In addition to the problems, described above, the researchers found that the dependent women were often hit extremely hard in the financial realm by their husband's death. Some of these women found themselves forced to live on social security or welfare - and often they could not make ends meet. Those widows who were young and heal thy enough to look for a job faced a multitude of problems. Some spoke of problems of low self-esteem and lack of confidence in the abilities to function in the demands of a work role. In addition, these women had few marketable skills and little education to meet the demands of the present job market. Generally they found themselves qualified only for the most menial jobs. To add to these handicaps, the widows frequently were faced with age discrimination by employers.

A final problem which seemed to plague the dependent widows was having no social network. One widow said, "I always depended on my husband for everything, rather than relying on friends. We didn't make an effort to meet others, we mainly did things together." Often it appeared that while the husband was still alive, the couple did spend time with friends who were mainly people the husband had met at work. Yet after the husband died, the widows spoke about abandonment by friends or feeling like a 5 th wheel. An overwhelming proportion of such responses were made by these dependent women.

We might conjecture that this rigid adherence to gender roles will 
be breaking down, especially amongst the younger members of American society. The advent of various women's liberation groups which seems to trigger much consciousness-raising among females may be responsible for what appears to be a disintegration of the rigid gender roles. More and more of our institutions seem to be giving women the message that the roles of wife and mother are not the only roles open to them. Some women are realizing that they are equal to men and have the right and potential to pursue whatever they want - and this most definitely includes a right to a career. Perhaps as women learn that they can develop their own identities and do not have to depend upon males (i.e. husbands) for their identities, the tragedy of widowhood will not have so great an impact upon them. Hopefully women will become more independent and will have the strength, desire, and skills to pick up and start rebuilding the world around them which collapses upon the death of the husband. 


\section{CHAPTER V}

\section{AGE}

Although widowhood is largely a problem of the aged, $(3 / 5$ of the widows are 65 years and older), one cannot discuss the problems of widowhood adjustment without examining the differences between the younger and the older widow.

One of the major differences that exist in adjustment to widowhood for the younger and the older woman is the influence of the era in which she matured. Beginning in the late sixties and continuing through the seventies, societal attitudes have been geared towards independence. The younger woman who matured in this era seems to be geared towards higher education, development of a career and maintaining an equal partner status within her marriage. The older woman, on the other hand, who matured prior to the forties, grew up in a society which dictated that education was not as important for women, that women marry young and raise a family as their career and that women be dependent on men. Thus, in the marriage, the wife was very dependent on her husband as provider and protector.

So how does this change of societal attitudes affect the widow in her adjustment to widowhood? The younger widow, since she has been geared towards independence, is more likely to be involved in an ongoing career than the older widow. Being career oriented is important in making adjustment to widowhood easier for three reasons. The first reason deais with the fact that a woman who works has a good part of her iden- 
tity invested in her role as a working person and may postpone a confrontation with her new identity of being a widow. Secondly, a career is helpful in adjusting to widowhood, because it provides financial security. And thirdly, a career provides the opportunity to be in constant contact with other people, thus helping the widow to feel less lonely.

For the older woman, raised in an era where ongoing careers were not accepted for women makes it especially difficult when she is forced to obtain a job in order to support herself. It is probable that the older woman who has never worked lacks the necessary educational and occupational skills to obtain a job in todays working market. This applies, as well, to the woman who had worked prior to marrying or in her early marriage, but has been absent from the job market for often times ten to twenty years. Furthermore, returning to school after having been away from an academic environment for many years, not to mention the cost of the schooling, makes it difficult for her to develop the skills necessary to obtain a job. In addition, she is subtly discriminated against by employers who feel that they cannot count on an older person to work over an extended period of time.

Children remaining in the home seems to be another aspect which makes a difference in how the younger woman and older woman adjusts to widowhood. Usually it is the younger woman who is still in the process of raising her children when she becomes a widow. Although raising children alone was mentioned as a difficult adjustment problem to widowhood by many of the widows, it was still felt that the children helped dispel some of the feelings of lonel iness that existed for the widow. The children seem to create an atmosphere of love, laughter and quar- 
relling that permeates their surroundings, as well as, occupy much of the widow's time.

Besides keeping the widow from feeling lonely, children tend to force the widow to look towards the future for herself and her family. For example, one young widow had three children under the age of thirteen living at home and was expecting her fourth child in about seven weeks when her husband died. She explained that she suddeniy was forced to examine what she and her family were going to do now that her husband had died. "Two days after my husband died I sat down with my family and said, 'We're here now and where do we go?' We need to make short term and long term goals." They decided as a family that the short term goals would include recovering the couch, buying a freezer, repairing the deck and buying a utility trailer. During the two and one half years widowed, all the short term goals were accomplished and they in turn, made new goals. Their long term goal was a trip to Disneyland, which they are still attempting to achieve.

It is important for the widow to begin to look towards the future in order to make her adjustment to widowhood easier, and children seem to be a great incentive for encouraging the widow to move ahead. What seems to make this move possible is the widow's extra concern of raising her children properly, since she is now faced with parenting alone.

In the case of the older woman who is suddenly faced with widowhood adjustment, the children usually have left home and have their own families. At least when the children left home, the older woman was able to direct her attention towards her husband. Now her husband is also gone. Faced with living alone and no longer in the role of mother or wife, leaves the widow with pervassive feelings of "emptiness" and 
"lonel iness".

This sudden void that exists for the older woman is magnified if the husband was retired. Retirement provided both spouses, with increased time to spend together and, as a result, possibiy intensified a dependency on each other for companionship. Many of the widows whose husbands were retired said they found it especially difficult to adjust to being alone, because the husband had previousiy been around 24 hours a day.

Upon becoming widowed, the direction of the older woman's attention had once again been forced to change. The first time was when the children left home. The problem facing the older widow then becomes one of trying to fill the void that exists for her and find a new direction in life.

Two of the factors which make it difficult for the older woman to get involved in activities and move in a direction towards creating a new life are her physical and health problems. Her body begins to move more slowly, her vision begins to be impaired, and she may not be able to think as clearly. She is likely to have an increased number of illnesses, including heart problems, emphysema and so forth. These problems inhibit the older woman's maneuverability.

A typical example of an older woman's physical and health problems affecting her adjustment to widowhood is a 79 year old widow, who was interviewed for this study. [She seemed totally distraught with her situation. After her husband died, her health changed "for the worse". Previously, her husband helped care for her, but now no one is available to provide that care. She is on a special diet which requires much time and energy for proper preparation of food. Further hampering her 
daily activities is a recent hearing impairment. She is no longer able to attend church daily because cold weather gives her an earache. Until she is able to afford a hearing aid, her difficulties will be increased since she is unable to hear the telephone ring or the doorbell, thus further isolating her from involvement with the outside world. She kept repeating that she was lonely and that she wanted to be around other people.

This widow is by no means in the minority of the older women who are widowed. Physical and health problems, can and often do, lead to social isolation for many. Social isolation has a definite impact on the widow's ability to find a new direction in life. Other factors also tend to contribute to this isolation.

One of the factors is that many of the older widows' friends avoid contact with the widow, because they are afraid of facing death. The widow is a reminder that they are getting old and that one of the partners, most likely, will die within a few years. It's especially difficult for their women friends who realize the high probability that they will become widowed.

Not only is it difficult for the older aged friends to keep in contact with the widow, but also young people, thus furthering the widow's social isolation. Generally, it is found that younger people feel uncomfortable around older people, especially if the older person's mental and physical abilities are degenerating. In addition, younger people have had little contact with death and are unaware of how to deal with it. Younger people are also involved in their own lives and raising their own families, thus limiting the amount of time they have available for providing attention to the widow. 
Another factor influencing social isolation for the older woman is the likelihood that she and her friends will have physical and health problems which prevent them from being able to visit.

Social isolation is further experienced by the widow who does not drive. Generally, it is the older woman who does not drive, because she grew up in a time where women were not expected to drive, since it was the man's responsibility. Not knowing how to drive limits the widow's accessibility to get involved with others, as well as, continues her dependence on others to take her places. This dependence becomes a problem since her husband is no longer available to provide this service, nor is anyone else available. One widow, 65 years old stated, "I'm depressed if I want to go somewhere. If someone says they'11 take me somewhere, then they don't, it hurts my feelings." Another widow. said that her family keeps inviting her over, but that she has no way to get there. She does not like to call and bother them to come get her.

Therefore, since the widow does not know how to drive and is dependent on others for transportation, social isolation becomes more of a reality. Attending sociai activities where she may visit with her friends or develop new friendships becomes difficult. How can the widow find a new direction in life if she is faced with the phenomenon of social isolation?

Social isolation as a phenomenon is not limited to the older widow. The younger widow also experiences as isolation after her husband dies, although she has a much better opportunity to overcome this isolation. For example, younger widows most likely have children living at home and, as a result, the children's activities provide the widow th the opportunity to get involved in various social networks. The younger 
widow probably works, which would also provide her with the opportunity to constantly be in contact with the public and possibly develop new friendships. Another factor which prevents the younger widow from social isolation is that she typically drives a car. And finally, younger women have available more facilities in which they can meet other people. For example, the increasing number of single groups has made it easier for the younger women to meet other people. Over the past few years, singles groups and bars have become more socially acceptable as a means of meeting people.

In conjunction with the younger widow's increased availability of meeting other people is the probability that more younger widows will remarry than the older widows. Being young and feeling like there is a good chance to remarry provides an incentive for the younger widow to want to continue to live and forsee a happy future.

In examining the issues which influence the younger woman's and older woman's adjustment to the problems of widowhood, one must conclude that adjustment to widowhood for the older woman is more difficult than for the younger woman. In no way should it be conceived that the younger woman does not have a difficult adjustment to widowhood, but rather she has more internal and external resources available to help her adapt to her new situation. Hopefully, there will soon be an answer for the widow who asked, "what future is there for a woman 65 years old." Age, however, is not the only factor which affects the future of the widow. Finances also seems to play a vital role in determining the widows future. 


\section{CHAPTER VI}

\section{FINANCES}

The widow's financial situation has a major affect on her adjustment to widowhood. She will most likely have a major decrease in income and, therefore, need to find some other means of support. For many of the widows, there will be a forced change in economic status, which may then reflect itself in a change in social status. In addition, management of finances is often a new experience and a problem for the adjusting widow.

More often then not, the widow experiences a major decrease in income when the husband was the main breadwinner or when his disability income or pension was not transferable to his wife upon his death. Some examples of decrease in annual income from widows interviewed in this study are: 1) $\$ 10,100$ to $\$ 5,300,2) \$ 24,000$ to $\$ 8,400,3) \$ 13,000$ to $\$ 3,300,4) \$ 6,000$ to $\$ 3,000$ and 5) $\$ 27,600$ to $\$ 11,000$.

As a result of the sharp decrease in income, serious economic problems develop for the widow. Having to support herself and possibly a family, she often must seek employment as an economic supplement.

For the older widow, the obstacles in the path of securing a job are much more serious. Because it is mainly the older widows who are unemployed, they are often less able to support themselves than the younger widows, and thus, become partly or wholly dependent on assistance from children, relatives and public or private funds. Even though social security has broadened and substantially increased its benefits for the 
widow, its benefits still fall short of meeting the older widow's basic needs.

One of the widows interviewed, who is 79 years old is a prime example of total dependence on public assistance which is unable to meet her basic needs. The widow presently receives, $\$ 3$ from welfare and $\$ 176$ from social security each month or a total of $\$ 2,112$ annually, clearly not enough to sustain even a barely adequate standard of living.

Furthermore, this widow is in dire need of a hearing aid. She went to get her $\$ 3$ welfare check which she had just received and said, I"I need a hearing aid that cost $\$ 400$ and welfare said they won't pay for it." Extremely upset, she said, "I don't know what to do!" Without a hearing aid she cannot hear the doorbell or the telephone ring and she wants very much to be in contact with people. She continued to say that she has lots of expenses, but that no money is coming in. "It's a big worry." She also mentioned that the house is in poor condition and that she is financially unable to hire anyone to make the necessary repairs.

When the widow was asked what would be helpful in making her adjustment to widowhood easier, she stated very sadiy, "financial help so I don't have to worry all the time and beg for charity." This widow, Iike many other widows, has a strong sense of pride, and asking for public or private assistance is a humiliation. What results is a feeling of helplessness, which therefore makes the adjustment to widowhood even more difficult.

Another widow who is 65 years old described her adjustment to widowhood as being more difficult because of her financial situation. She was forced to change her place of residence, as well as obtain a job, 
due to financial 1 imitations. Before her husband died, their total annual income was approximately $\$ 10,100$. After he died, it sharply decreased to approximately $\$ 3,200$. Her husband was a paraplegic the last ten years of his life and, therefore, received disability income. But he died of cancer, which made her ineligible to receive his disability income payment after his death. Those payments had amounted to $\$ 600$ a month. She applied for widows benefits from the Veterans Administration and she was able to receive $\$ 20.60$ per month on the stipulation that she would not earn more than $\$ 100$ a year. Thus, this widow's monthly income included $\$ 20.60$ from V.A., $\$ 11.12$ from school pension and $\$ 233.11$ from social security for a total of $\$ 263.83$ per month. Like the previous example, this amount was insufficient to meet her needs. As a result, this widow had to move to a cheaper apartment and seek employment. She was able to obtain a part-time job at $\$ 2.60$ per hour. Having a job made her ineligible for the Veterans Administration benefits, but she realized she could still earn more by working. This job enabled her to increase her income from $\$ 3,200$ to $\$ 5,600$ annually.

It is extremely unusual that a woman at the age of 65 is able to secure a job. The employer, also a widow, told us that the widow was having a very difficult time adjusting to widowhood and that she wanted to help her as much as possible.

A major difficulty which often occurs in conjunction with the widow's change in economic status is a change in her social status. The widow finds that she is unable to afford to do the things she used to, such as continuing hobbies, going to operas and concerts, travelling, and so forth. Thus, she becomes uncomfortable around her friends who still do enjoy these activities. Suddenly, the widow realized she is 
now in a different social class. Closely associated with this realization is the phenomenon of social isolation.

One of the widows interviewed for this study experienced a change. in social status and subsequent social isolation which resulted from her changed economic status. This widow is 66 years old and has been widowed for four years. While her husband was living, their joint annual income was $\$ 12,000$. Presentiy, her annual income is $\$ 3,300$ which comes from social security. She described her situation as catastrophic. His pension did not go to her and most of the savings that she and her husband had accrued during the years were spent on doctor bills for her husband's illness. In addition, she was unable to work during the four years of her husband's illness, because she had to attend him. She returned to work as a nurse, but she stated that she found her frustration level lower and that she was more nervous, as a result of the long term care for her husband. Two years after her husband died, she had a heart attack (1974) and one year later, she had gall bladder surgery. To complicate matters, her daughter had a nervous breakdown around the same time and the widow found that the rest of her savings went towards medical care for her daughter. With her savings totally depleted and no longer working, this widow is now receiving $\$ 275$, a month from social security.

The widow describes herself as being "socially isolated," because of her lack of finances. She says she can't afford to buy clothes, and, therefore, feels uncomfortable around her friends. In addition, she cannot afford to maintain or develop new interests, which further isolates her from existing friends or prevents her from making friends. She said, 
I'd like to have more stimulating contacts as far as people and places are concerned. I'd love to go to operas and concerts, but it's the money.

She continued to say that she is a "prisoner" of her frustrations financially, socially and with her daughter. She says that she is "emotionally-overloaded" and that she cannot handle things now.

If things don't change like getting work, making friends and better health, I'm going to commit suicide. I'll give it one more year.

The financial stress that this widow is experiencing is by no means atypical. Feeling helpless and hopeless, she is constantly trying to seek solutions to the problem, but feels it is an endless road. (This woman experienced the highest amount of stress points, out of all the women interviewed in this study, and therefore she will also be discussed in the chapter on "Stress and the Social Network, as Mrs. L.)

One factor which should not be neglected in discussing the finances of the widow and their impact on her adjustment to widowhood, is the widow's sudden responsibility for managing her finances alone. More of ten than not, especially for the older widow, managing the finances is a new experience. Usually it was the husband's responsibility to make all the financial decisions and pay the bills. Many widows describe this phenomenon as having been the husbands' desire to protect them. In reality, though, this "protection" leaves the widow unaware of her financial situation and lacking in skills in the area of finances. Thus, suddenly having to assume the sole responsibility of managing the finances after the husband's death adds to the widow's difficulty in adjusting to widowhood. 
It becomes quite apparent that the financial situation of the widow has a major impact on her ability to adjust. In essence, the widow is prevented from taking positive and appropriate steps towards developing a new direction in life, because of her stressful financial situation. The full impact of stress, which the widow experiences, will be discussed in the following chapter. 
CHAPTER VII

STRESS AND SOCIAL NETWORK

It is a well known fact that stress and the onset of physical and/or mental illness are related. Thomas Holmes and Richard Rahe ${ }^{1}$ were interested in this phenomena with special emphasis on the intensity of stress caused by various life events. Holmes and Rahe developed a cluster of 43 life events which pertain to major areas of significance in the American social structure. There was one common theme among all of these life events - the occurrence of each required some adaptive or coping behavior by the individual involved, thus being indicative of a significant amount of change in the ongoing life pattern of the individual. Each life event was assigned a readjustment value, the readjustment value measuring the intensity and length of time necessary to accommodate the change. "Death of a spouse" assigned a value of 100 was seen as the life event requiring the greatest degree of readjustment, followed by marriage with 73 points, ranging all the way down to "Christmas" with 12 points.

In this study we were interested in this stress/situation concept leading to the onset of illness in relation to widows. Since stress was equated to situational life changes by Holmes and Rahe, we assumed that these life changes would manifest themselves in symptoms of depression. It is important to remember that symptoms of depressive disorders can be

1Thomas, Holmes and Richard Rahe, "The Social Readjustment Rating Scale," Journal of Psychosomatic Research, 11 (1967) p. 213-218. 
classified into four areas which were discussed in Chapter I.

With the preceding in mind, we developed the following assumption: "Stress and depression caused by widowhood problems can lead to physical and/or mental health changes of the widow, thus making her adjustment to widowhood more difficult." In an effort to gain some insight into this assumption, we administered the Social Readjustment Rating Scale and the Zung Depression Test to all interviewees. It should be noted that there is a self-rating statement on the questionnaire which stated, "During the 6 months prior to my husband's death and 6 months after my husband's death, my health has changed." And if widows felt their heal th had changed, they were asked to describe the changes.

Speculations revolving around the above assumption based on information gathered from the widows as well as the literature review follows. Two of the five widows who were more depressed than normal on the Zung Depression Scale also experienced serious health changes. Widows when asked to describe health changes prior to and after the husband's death described problems such as losing weight, feeling tired, nervous, restless, being unable to perform simple tasks, crying, screaming, angry, lumps in chest, suicidal thoughts and arthritic attacks.

At this point it should be noted that throughout the interviews, most widows had expressed feel ings of confusion, emptiness, hopelessness, indecisiveness, irritability and dissatisfaction. As we previously indicated, these symptoms are classified under psychological manifestations of depression, often resulting from situational stresses - thus being indicative of a mental health change. However, when the widows were asked to describe health changes they experienced, these difficulties were seldom mentioned in respect to heal th changes. Rather the physio- 
logical symptoms were emphasized here by widows. So it appears that most widows interviewed had some sort of mental health change, al though we had few direct responses on the question concerning health.

There is little doubt in our minds that the situational stresses caused by the readjustment problems of widowhood previously discussed (being a 5 th wheel, loneliness, finances...) contributed greatiy to these health changes. Generally these physical and/or mental health changes are worked through and adequately coped with during the normal grief process (described in the literature review) which is expected to last roughly one year. However if the widow is not able to adequately cope with her difficulties, serious long term physical and/or mental health changes can result. One widow said,

About one year after my husband's death I started having high blood pressure, became extremely nervous and was on the verge of a stroke.

Another widow said,

Yes, I was tired, exhausted and nervous from the long term care; I was never of a nervous temperament and that's why I noticed it; I had a lower frustration level - it took less to upset me; I had a heart attack 2 years after he died:

From comments like the above and symptoms of physical and mental health changes of the widows that we have discussed, little more comment is needed on the relationship between stress and depression and health changes making widowhood adjustment more difficult. However, we did want to look at a related assumption which postulates, "If stress is high and the availability of a social network is not developed, widowhood adjustment is more difficult." We assume that if a widow has a satisfying social network (friends, immediate family, and relatives) to 
whom she can turn, stressful problems of widowhood can be greatly minimized thus leading to a better adjustment.

Obviously, no one person or group of people could ever fully compensate for the absence of the widow's husband. But a well developed social network can prove a valuable resource for providing love, care, concern, kindness and attention for a widow who generally is needing much emotional support. For a widow, it surely would serve as a great relief if she could telephone a friend or relative to help cope with her loneliness. Even better, would be having a friend or relative spend some time with her. According to our sample, often essential to the physical and mental well-being of a widow is having someone around to whom she can express her feelings about being a widow. Yet as already has been said, many people seem fearful of a widow's expression of her feelings. A few of the widows interviewed mentioned something to the effect that when they tried to express feelings to friends, friends withdrew or told the widow to stop feel ing sorry for herself. By the way, the widow's ability to express feelings is considered an essential constituent to a healthy outcome of the bereavement period.

In reference to the more concrete problems of widowhood such as having no one around to fix things, decision-making, a social network system could alleviate much of the widow's stress. The widow could call a friend or relative to help with household repairs, could contact someone perhaps to help her make an important decision which at this point she may feel she cannot make alone...

Perhaps what we have said above seems elementary and simple to the reader. However an extraordinarily large number of women find themselves in total social isolation after the husband's death. Many of the 
interviewees said that friends and family were around the first few weeks after the husband's death but were seldom heard from or seen again. Perhaps they just did not understand the great need a widow has for their support.

A brief look at Mrs. L., a widow interviewed for this study, may help clarify the concepts of stress and social network discussed in this chapter.

Mrs. L. is 66 years old, had been married for 36 years and has been a widow for the past 4 years. Mrs. L's husband had been an alcoholic for the 20 years preceding his death. Mrs. L. said that because of her husband's drinking problem, they had few friends and seldom, if ever, saw relatives. Mr. L. had been seriously ill for the 4 years prior to his death, forcing Mrs. L. to quit her job and stay home to care for him.

Mrs. L. was administered the Social Readjustment Rating Scale and had a total score of 632 indicating the presence of an extreme amount of stress. Stress seemed to be related to the loss of her husband, her own poor health, the loss of her job, health problems of her daughter, a decreased income, a change in church activities, a change in social activities and fewer family get-togethers.

When the researchers inquired about Mrs. L's present social network, it appeared that she had a very poorly developed one, one which further decreased after her husband's death. As for her family, the only relative she had contact with was a sister who lived in Portland. She generally went out with her sister once or twice a week but was seldom invited to spend time with her sister's family.

Mrs. L. spoke frequently about having few friends and seldom partaking in recreational activities. Her comments indicated that she had often been hurt by people and found it difficult to form good friendships. Mrs. L. claimed that few people she knew were intellectually stimulating and she did not know how to meet that type of person. Rather, she seemed to feel it was better to be lonely and isolated rather than to have "unstimulating" friends, even though this was an extremely painful situation to her. Mrs. L. had a similar attitude towards recreational activities indicating that operas and concerts offered her stimulation. However, because her husband's illness used up their life savings, coupled with the loss of his pension and her jobi, she could no longer afford the stimulating social activities. So she sat home all alone.

Mrs. L. was tired and exhausted after the long term care of her husband. She had also become extremely nervous and was frustrated easily. About 2 years after her husband's death, 
she had a heart attack. Less than a year ago, she had gall bladder surgery.

Overall, Mrs. L. appeared to be a very unhappy, isolated person without much hope for a brighter future. Towards the end of the interview. Mrs. L. stated that she needed to find friends, wanted a job and improved health. She said she would be willing to wait another year for these things - if not suicide was a definite consideration for her.

So typically a widow may be an older woman, one who seldom gets out of the house, with few or no contacts with friends and relatives leaving her in virtual isolation. Can it really be of any great surprise that widows experiencing a high amount of stress and who having. no social network to turn to; often faces insurmountable obstacles in adjusting to problems of widowhood? Perhaps this can account for empirical findings showing that the widowed have higher death rates, a greater incidence of mental disorders and a higher suicide rate than their married. counterparts. 2

In order to help prevent the development of mental disorders, and possible suicide, we felt the necessity to include a chapter of suggestions to make widowhood adjustment easier for new widows.

2Felix M. Berardo, "Widowhood Status in the United States: Perspective on a Neglected Aspect of the Family Life Cycle," The Family Coordinator (July, 1968), p. 196. 
CHAPTER VIII

\section{SUGGESTIONS FOR NEW WIDOWS}

During the course of this study we have often heard it said that a woman who is a widow is the only person who can understand the full meaning of what someone else experiences during widowhood. With this in mind it seemed most appropriate that a chapter focusing on suggestions and advice that would be helpful for a new widow in dealing with widowhood problems should be largely written by the experts themselves, other widows. And this chapter was.

The question upon which this chapter is based is, "What advice would you give to new widows?" The most frequently given response was to get involved and keep busy. Underlying this response seemed to be the realization of how great a problem loneliness is for the new widow. As Many widows indicated, when first widowed they found themselves with a great deal of time on their hands. They sat around feel ing sorry for themselves, dwelled endlessly on the subject of their husbands' death and generally made themselves miserable.

Activities the widows suggested to keep thenselves busy varied. Some widows emphasized the need to keep in contact with old friends especially those people who are willing and wanting to be supportive of you. One widow said, "During the first few months after becoming a widow, I talked to friends everyday. It really cheered me up." Again it was emphasized by our interviewees that other widowed friends were the best people to turn to. On the other hand, other widows said that 
you must not depend on old friends and you must strive to make a new life for yourself. And a constituent part of the new life seemed to be the formation of new friendships through social activities. As one widow mentioned:

The chances of getting remarried are slim so you may as well have friends whom you can depend upon to be there if you need or want some company.

Widows also suggested that through jobs, work in voluntary organizations, membership in clubs and widow groups, card playing, classes and travel, the new widow will have excellent opportunities to meet people. One of the more energetic widows when speaking about getting involved and keeping busy said:

Get out and go places. I joined clubs (Odessy, Sr. Citizens, Steelhead, Mushroom Society). I got recreational and physical activity. I made up my mind to seek companionship and/friends and not to sit around. I took night classes (sewing, cooking, upholstery, stitchery, Spanish) to fill my nights and not feel sorry for myself. I met new friends and got out. I haven't lost married friends, they still invite me over. And I aiso started travelling. Finally, I took in a boarder with a child to help cope with my lonel iness.

Closely associated with the above suggestion of getting involved and keeping busy was further advice which basically stated that widows should have a positive attitude about the future. Interviewees who gave this advice seemed to say that widows should not try to forget about the past; rather they should remember the good things from the past and be grateful they have those beautiful memories. But too much dwelling on the past could be destructive. Rather the widow must look forward and plan for her future. 
One widow aptly stated:

Don't sit around and brood about your loss. Of course, there is a certain period of time to grieve but when you find your:self going nowhere then it is time to stop. Think about what you want from your life now and how you are going to get it. The sooner you start building a new life, the better your adjustment will be.

Do not make any decisions during the first year of widowhood was also a frequent suggestion for new widows. Our interviewees said that the new widow is vulnerable and does not exercise good judgment because she is initially confused and upset by her new situation. It was advised that decision-making should be postponed until the widow can fully accept what has happened to her and is able to decide what she wants to do with her life. Too often our interviewees said, the new widow makes rash decisions concerning their homes, finances, giving away their husband's personal belongings... But a few months later, widows often regret their decisions.

It was also advised that if the widow finds she is forced to make any major decisions within the first year, she should turn to family and friends for advice about them. One widow when speaking of decisionmaking during the first year of widowhood said that her daughter made many of them for her. She went on to say that she and her daughter had reversed roles - her daughter became the adult and she became the child.

Another suggestion given to help new widows involved the expression of feelings. Our interviewees said it was important to face the fact that the husband was really dead and never was going to come back again. Along with this reality comes feelings of depression and loneliness but these feelings will gradually lessen. And to best cope with 
these feelings, it was indicated that the new widow should express them - not keep it all bottled up. Ways that were suggested for the new widow to deal with her feelings varied. One widow said that she found it helpful to scream while hitting a punching bag. Other widows said that friends can be extremely good listeners. Some widows said that talking with someone in the same situation (i.e. other widows) helped them deal with their feel ings. Several interviewees said that reading general information about widowhood including autobiographies by other widows let them know that the feel ings they were experiencing were normal and this in itself was a great comfort.

There were also several other suggestions given to help the new widow. Some interviewees advised the new widow to turn to religion and God to help them accept what has happened and to gain the desire to go on living. Some of these women also found their church ministers extremely helpful. One widow who had several young children living at home spoke at length about the support she had received from her minister in regard to parenting alone. Some interviewees advised the new widow to seek some kind of professional help to deal with problems of widowhood. A number of interviewees said the new widow should learn how to drive if she does not know how to. Driving seemed to be essential to the widow's 'freedom' - being able to go places, visiting. friends, going shopping...

A final and interesting piece of advice given by our interviewees was that widows should not pay attention to criticism given them for a short grieving period. 
As one widow said:

There is no reason to feel guilty and to apologize for going out and enjoying yourself. It's okay to feel good. Do what is best for you.

We believe that there were many excellent suggestions given by the widows during the interviews. We added few of our own comments throughout the chapter as this section really belongs to the 'experts' - those people who are experiencing widowhood. 
CHAPTER IX

\section{SOCIAL SERVICES FOR WIDOWS}

This chapter will be divided into two sections. The first sec-' tion will be a general evaluation of widowhood programs in the Portland metropolitan area. (For descriptions of the programs, see Chapter Two.) The general evaluation will include the widows' initial reasons for joining a widowhood program, what the widows found helpful about such a program, as well as suggestions to improve the program. In addition, we will examine the reasons of those widows who decided not to join a widowhood program.

The second section of the chapter will deal with suggestions for increased social services for widows in the Portland metropolitan area, which would help them in their adjustment to widowhood.

\section{SECTION I}

One half of the widows interviewed in this study decided to join a local (Portland area) widowhood program. Although the sample size is small in this study, the reasons the widows indicated for initially joining such a program were very similar.

One of the major reasons voiced was a desire to "meet other people" and "find companionship." Since the widow no longer fits into the same circle of friends that she had while her husband was living, she realizes that she must develop new relationships. It appears that the widow makes a conscious effort to meet other single people, especially those who have 
also experienced the loss of a loved one. The philosophy behind this attitude, according to many widows, is that two people who have shared a common experience will be better able to understand each other and provide the necessary support for each other. As one woman stated:

There is a feeling of kinship in that you are around people who have the same problem and they really understand.

Comparing experiences about coping with the problems of widowhood is also part of the reason for wanting to meet others who are widowed. "I wanted to compare experiences and check out to see if my experiences were bizarre or if they were normal."

In addition to wanting to meet other people and find companionship, the widows also stated that they joined the program because it would get them out of the house and provide them with an activity. Keeping busy and getting involved in groups helps the widow deal with her loneliness and the void that exists for her, according to the widows interviewed in this study.

The last major reason for joining a widowhood program was because of the program format. The widows were looking for new ideas which would help them in their adjustment to the problems of widowhood -- "I wanted to see if they had a new approach to things -- like how to adjust or ideas of where I could be helped."

Having discussed the major reasons for joining a widowhood program, we will now examine what was helpful about the program. It immediately became evident that getting together with other widows and developing new friendships were the greatest benefits of the program. The widows realized that they were allowed to express their grief and that there 
was support and caring amongst the people in the program.

The next most helpful aspect of the program, indicated by the widows, was having speakers who dealt with issues of widowhood adjustment. Some of the issues discussed were: finances, legal advice, how to fix things, grieving, sexuality, and so forth. A common response was "I have found that the subject matter the program dealt with to be extremely helpful." The speakers provided the widows with the opportunity to share ideas about dealing with their problems of widowhood.

It is apparent that those widows who decided to join a widowhood program felt that the program provided them with what they had expected-companionship, support, an activity and information in dealing with the problems of widowhood. As one widow stated, "my personal growth since I have been in the widowhood program has been outstanding". Although the general concensus is pleasure with the widowhood program, the widows did indicate the need for improvement.

One of the main suggestions for improving the widowhood program is to increase the number of men who would participate in the program. The reasoning behind this suggestion was not based on having a male for dating purposes, but rather the desire for a male point of view. This suggestion came from both younger and older widows.

More publicity about the widowhood program, another suggestion given by the widows interviewed, might encourage both men and women who are recently widowed to participate in the program. It is felt by the widows that outreach is especially important to those who are newly widowed.

In addition to the above suggestions, the widows expressed a need to form small discussion groups, in order to promote more one to one 
relationships. Not only would it provide more one to one relationships, but it would also provide a non-threatening situation for those individuals who find it difficult to discuss in large groups.

Some of the widows also suggested that the program have more social activities. The widows felt that at times they just wanted to have fun and put aside discussing their problems of widowhood.

The last suggestion was to help other widows by visiting them in their homes. It was suggested that the widowhood program form visitation groups so that they could provide an outreach service to those widows and widowers who are unable to attend the program or to those who might be hesitant to join.

Reaching out and helping other widows, as well as helping themselves seems to be a theme for those widows, in this study, who participated in a widowhood program. Rather than becoming totally inward and enveloped in their own problems, they are able to look beyond and give of themselves. This approach seems to be positive in that the widows feel useful and are goal-oriented. We wonder if part of this desire to help others is because of the widow's own environment, where there might possibly have been a lack of support or not enough support. It is most likely that upon entering the widowhood program, the widow found that she was able to meet new people who also shared the same experiences and provided the understanding and support that was necessary for her. Therefore, in turn, she wanted to provide the same understanding and support for other widows, by developing an outreach program. In fact, if an outreach program did exist, whether in the form of more publicity or visitation groups, more widows possibly would have joined the program, which leads us to the next point. Why did the widows, in this study, decide not to belong to a widowhood program? 
One of the major reasons why the widows, in this study, did not belong to a widowhood program was just for that reason previously indicated--they did not know that such a program existed. A few added that if they had known about the program, they would have joined.

The other major reason why the widows did not belong to a widowhood program was because they felt that they did not need the program. According to the widows, it was not the way they liked to meet people and they did not want to be associated with a program for widows. One widow stated,

I have always worked things out for myself and I do okay. I do not want to be identified with widows. I hate the expression and it took me a long time to get used to it.

And finally, some widows felt they were to busy to get involved in a program.

In conclusion, not all widows are geared toward joining a widowhood program, but for those who do, it serves a beneficial purpose. It is extremely difficult to determine, if the widows who do decide to join a widowhood program, are those who are already dealing with their problems of widowhood and are ready to move towards creating a new life for themselves, or if it is those widows who are having a difficult time dealing with their problems of widowhood.

\section{SECTION II}

This next section of the chapter deals with suggestions for increased social services for widows in the Portland metropolitan area. The widows, in this study, were asked to indicate what they felt they would like to see in Portland that would be helpful to widows? Their 
suggestions seemed to fall into four categories: 1) widowhood programs and groups, 2) a Widowhood Resource Center, 3) financial assistance and 4) education.

The need for more widowhood programs seemed to dominate the suggestions given by the widows. Even the women who do not belong to a widowhood program felt that Portland needed to have more. One widow stated, "it's a decent place to go and meet people. I would like one in every section of the city."

The widows also felt that they would like more churches to sponsor widowhood programs. Many women stated that they felt it was the responsibility of the church to help the widow, but that the church was neglectful in this area. Besides having more churches getting involved in widowhood programs, the widows also stated that they wanted more social clubs, such as: Kiwanis, Lions, Rotary and so forth, to sponsor widowhood programs.

In addition to more widowhood programs, the widows also wanted encounter groups, therapy groups or just "rap sessions." In conjunction with this suggestion, the widows emphasized the need to have specialized counselors in the area of widowhood adjustment, who could faciliate the groups.

Widowhood programs and groups are felt to be important in helping the widow in her adjustment to widowhood. It seems, though, that a central social service agency is lacking in the Portland metropolitan area, according to the widows in this study. Essentially, the widows are suggesting a Widowhood Resource Center.

One aspect of the Widowhood Resource Center, as suggested by many of the widows, would be a widow hot line. According to one widow, she 
would like the phone number to be $W-I-D-0-W$ and wants it to be distributed by the funeral homes. "I want to be able to talk with other widows. If I would have had such a number to call, I would have said, 'Hi, I'm lonesome.' I want someone that can relate to me." Another widow, who was interviewed during the pilot study, felt a dire need for such a hot line. She emphasized how much she needed help and that she had no one to whom she could turn. She said she finally resorted to calling Suicide Prevention, but that she ended up giving them advice. A list of available widows who would be willing to talk to other widows was al so suggested.

In addition to the above, the widows, in this study, would like the Widowhood Resource Center to include a list of available resources, such as: a list of activities being offered throughout the city for widows, locations and telephone numbers of Senior Citizen Centers and governmental agencies and lists of available books on widowhood adjustment. One widow who indicated the need for a list of books on widowhood adjustment said,

It's helpful to know what's going to happen to you during certain stages of widowhood. Having a knowledge of books that offers this, gives you a good feeling in that you know that others have gone through it too:

The widows also suggest the need for a homemaker service and a free counseling service, which might also be a part of the Widowhood Resource Center. The homemaker service would be geared towards providing: 1) help for the widow who is sick, 2) child care so the widow can get out of the house and 3) transportation to activities for those widows who otherwise would not be able to attend. The free counseling service would include legal advice and consultation for the widow who wants help 
in making decisions.

In essence, the widows want to be able to turn to one place which will provide them with the necessary help to make their adjustment to widowhood easier. Widowhood Resource Centers, similar to the one suggested here, do exist in other large cities and have been proven to be quite successful in aiding the widow in her adjustment to widowhood.

In addition to more widowhood programs and groups and a Widowhood Resource Center, the widows suggested that Portland needs to provide more financial assistance for the widow, such as: 1) increasing the number of low income housing projects, where singles, pets and children are allowed, 2) deductions on medications and 3) a concentrated effort in hiring senior citizens who are still able to work.

And finally, education about the problems of widowhood adjustment for the general public, as well as, for the widow, was suggested in order to help the widow. In educating the general public, one widow stated:

We need more community education to let the public know that friends are needed and that there is no reason for friends to disassociate themselves with widows. We need friends more now than before. It is like widows have leprosy, that we are tainted by death and if "friends" come close to us, they will die. Let them know to be supportive and stay supportive.

Educating the public also included the need for changing the attitudes towards being a couple-oriented society. One widow said she hated it when she would go out for dinner and the hostess would say, "dinner for two" when the widow was standing alone.

As for educating the widow, it was suggested to have classes on widowhood adjustment through the community colleges. These classes 
would concentrate on the problems of widowhood and ways in heiping the widow deal with the problems. It is felt that such a class would help the widow better understand herself, as well as provide an opportunity for widows to get together and provide support and understanding for each other. This approach seems similar, though, to the widowhood programs in Portland.

In conclusion, the suggestions provided by these widows seem extremely realistic. Two steps are necessary, however, in order to make these suggestions become a reality. The first step is public awareness of the needs of the widows. The second step, is once the needs have been recognized, financial support would be essential to develop the necessary social services which would make widowhood adjustment easier.

Presently, the Portland metropolitan area is lacking in social services to the widow. Although Portland does have three widowhood programs, all of which have similar formats, not many people know about these programs. Therefore, only a few are benefitting from the services.' If a Widowhood Resource Center was established and heavily publicized, more widows would probably be helped, since there would be a variety of services offered. It is the opinion of these authors, that a Widowhood Resource Center is of necessity, in order to provide effective social services to the widows of the Portland metropolitan area. 


\section{CHAPTER $X$}

\section{CONCLUSIONS}

In our study, it was quite evident that loneliness was the major problem widows faced. Lonel iness not only encompassed a sudden lack of companionship, but often involved questioning whether life was worth living without the partner. It seemed necessary for the widow to partially fill the void or emptiness left by the husband in order to have the desire to continue living and create a new life for herself.

To fill this emptiness or void, the widows stressed that it was essential to have a developed social network system. It would seem likely that friends and family would come to the aid of the widow during the time when she requires much emotional support, but in reality, friends and family virtually disappear. Why such a paradox?

It appears that societal attitudes toward death break-down the widow's social network system. We, as a society, are afraid of death and, therefore, try to avoid any contact with it; the widow serves as a reminder of the inevitability of death.

Feel ings of being uncomfortable with the subject of death seem to override any desire to meet the needs of the widow. If any attempt is going to be made to help the widow deal with her problems of widowhood, we conclude that it is absolutely essential that our societal attitudes toward death need to be changed.

Not only must societal attitudes toward death be changed, but it is also essential that we become aware of how a social network system 
could effectively deal with the problems widows face. Granted, no one could ever fully replace the husband's absence. Yet, a concentrated effort by friends and family could certainly help the widow by providing her with attention, love, care, concern and the emotional support which she so greatiy needs. Some of the ways this may be accomplished are by: 1) allowing the widow to openly express her feelings, 2) visiting, phoning and/or writing the widow frequently, 3) inviting the widow to go shopping, out to eat, to movies, etc. and 4) helping the widow resolve difficult decisions. These suggestions are basically aimed at preventing the widow from becoming socially isolated and experiencing the abysmal loneliness and hopelessness which many of the widows spoke of in the study. Furthermore, these suggestions will help the widow become involved in the mainstream of life and facilitate her finding a direction for her future.

An important obstacle, though, which needs to be considered, relative to the integration of the widow into the mainstream of life is the couple-orientation of our society. This couple-oriented society presents a subtle discrimination against single people in that many activities and gatherings are geared toward couple participation. If we are to. help the widow resume a fulfilling life, we need to recognize this discrimination by planning for and accommodating single people.

To further help the widow adjust to the problems of widowhood, we must actively seek invoivement from governmental agencies, social organizations and religious institutions. Existing widow to widow programs must be expanded, but we must also continue to develop more programs such as a Widowhood Resource Center. This Widowhood Resource Center should include: 1) a widow hotline, 2) a homemaker service, 3) free counsel ing 
service and 4) lists of avallable resources such as: activities being offered throughout the city, locations and telephone numbers of governmental agencies and lists of reading material concerning widowhood adjustment.

The suggestions that have been provided here are essential, yet in order for them to be implemented, we must begin by increasing publ ic awareness about the problems of widowhood and what would be helpful in dealing with the problems. Two valuable ways of educating the public are by: 1) providing classes on the plight of the widowed and 2) encouraging further research into widowhood.

The purpose of our study was to begin to increase public awareness about problems of widowhood. We feel that we have accomplished this, but due to the small sample size, we were not able to generalize our findings to all widows. In addition to the limitation of the sample size, our questionnaire only examined a few specific areas of the problems of widowhood, thus leaving many areas to be further researched.

In conclusion, we feel that some of the areas which need to be further researched include: 1) the development of an effective social network system, 2) satisfaction with the relationship with the husband and its effect on widowhood adjustment, 3) differences between younger women and older women who are widowed, 4) cultural differences in widowhood adjustment, 5) the effect of length of time married and widowhood adjustment, 6) the effect of existing widowhood programs on widowhood adjustment and 7) the adjustment differences between widows and widowers. 
Abrahams, Ruby Banks. "Mutual Help for the Widowed." Socjal Work, (September 1972), 54-61.

$\checkmark$ Berardo, Felix M. "Widowhood Status in the United States: Perspective on a Neglected Aspect of the Family Life Cycle." The Family Coordinator, (July 1968), 191-202.

Caine, Lynn. Widow. New York: William Morrow and Co., 1974.

Decker, Bea. "Ways to Help the Widowed." Leader Guidebook, (March 1974), 8-10.

- Engel, George L. "Is Grief a Disease?" Psychosomatic Medicine, 23 $(1961), 18-22$.

Frankl in, Paula A. "The Disabled Widow." Social Security, (January 1973), 20-27.

Mfulton, Robert. "Death, Grief and Social Recuperation." Omega, (1970), $231-28$.

Gl ick, Ira and Robert Weiss. The First Year of Bereavement. New York: John Wiley and Sons, 1974.

- Holmes, Thomas H. and Richard Rahe. "The Social Readjustment Rating Scale." Journal of Psychosomatic Research, 11 (1967), 213-218.

Lind, S. Donna and Donna Jette. Handbook on Widowhood Adjustment. Portland: Portland State University Adult Learning Center, 1975.

\Lopata, Helena Z. "Living Through Widowhood." Psychology Today, (July 1973), 87-96.

Lopata, Helena Z. Widowhood in an American City. Boston: Schenkman Publ. Co., 1973.

YParkes, Murray C. "Effects of Bereavement on Physical and Mental Health A Study of the Medical Records of Widows." British Medical Journal, 2 (1964), 1-15.

Silverman, Phyllis R. "Services for the Widowed During the Period of Bereavement." Social Work Practice, (1966), 171-189.

Silverman, Phyll is R. "Widowhood and Preventive Intervention." The Family Coord inator, (January 1972), 95-102.

Silverman, Phyll is R: "The Widow as a Caregiver in a Program of Preventive Intervention with Other Widows." Mental Hygiene, 54 (1970), 540-547. 
Vancouvering, Virginia A. "Workshop on Widowhood Adjustment." Seattle, Wa., (Spring 1976).

Zung, William K. The Measurement of Depression. Cincinnati: MerrellNational Laboratories, JuTy $197 \overline{5}$. 


\section{ZUNG SELF-RATING DEPRESSION SCALE}

\begin{tabular}{|c|c|c|c|c|}
\hline Name & \multirow{2}{*}{$\begin{array}{l}\text { None OR } \\
\text { o Little } \\
\text { of the Time }\end{array}$} & \multirow[b]{2}{*}{$\begin{array}{l}\text { Some of } \\
\text { the Time }\end{array}$} & \multirow[b]{2}{*}{$\begin{array}{l}\text { Good Part } \\
\text { of the Time }\end{array}$} & \multirow[b]{2}{*}{$\begin{array}{l}\text { Most OR All } \\
\text { of the Time }\end{array}$} \\
\hline Age $\quad$ Sex $\quad$ Date & & & & \\
\hline \multicolumn{5}{|l|}{ 1. I feel down-hearted, blue and sad } \\
\hline 2. Morning is when I feel the best & & & & - \\
\hline \multicolumn{5}{|l|}{ 3. I have crying spells or feel like it } \\
\hline \multicolumn{5}{|l|}{ 4. I have trouble sleeping through the night } \\
\hline \multicolumn{5}{|l|}{ 5. I eat as much as I used to } \\
\hline \multicolumn{5}{|l|}{$\begin{array}{l}\text { 6. I enjoy looking at, talking to and being } \\
\text { with attractive women/men }\end{array}$} \\
\hline \multicolumn{5}{|l|}{ 7. I notice that 1 am losing weight } \\
\hline \multicolumn{5}{|l|}{ 8. I have trouble with constipation } \\
\hline \multicolumn{5}{|l|}{ 9. My heart beats faster than usual } \\
\hline \multicolumn{5}{|l|}{ 10. I get tired for no reason } \\
\hline \multicolumn{5}{|l|}{ 11. My mind is as clear as it used to be } \\
\hline \multicolumn{5}{|l|}{ 12. I find it easy to do the things I used to } \\
\hline \multicolumn{5}{|l|}{ 13. I am restless and can't keep still } \\
\hline \multicolumn{5}{|l|}{ 14. I feel hopeful about the future } \\
\hline \multicolumn{5}{|l|}{ 15. I am more irritable than usual } \\
\hline \multicolumn{5}{|l|}{ 16. I find it easy to make decisions } \\
\hline \multicolumn{5}{|l|}{ 17. I feel that I am useful and needed } \\
\hline 18. My life is pretty full & & & . & \\
\hline \multicolumn{5}{|l|}{ 19. I feel that others would be better off if I were dead } \\
\hline 20. I still enjoy the things I used to do & & & & \\
\hline
\end{tabular}

Zung, William.K. The Measurement of Depression Cincinnati: Merrel National Laboratories, July 1975 , 


\section{SOCIAL READJUSTMENT RATING SCALE}

Thomas H. Holmes and Richard H. Rahe

Directions: Please place an " $X$ " next to these life events which have created stress for you between the period of 6 months prior to your husband's death and 6 months after your husband's death.

\section{LIFE EVENT}

Death of a spouse

Divorce

Marital Separation

Jail Term

Death of a close family member

Personal injury or $i 1$ iness

Marriage

Fired at work

Marital reconciliation

Retirement

Change in health of family member

Pregnancy

Sex difficulties

Ga in of new family member

Business readjustment

Change in financial state

Death of close friend

Change to different line of work

Change in number of arguments with spouse

Mortgage over $\$ 10,000$

Foreclosure of mortgage or loan 


\section{LIFE EVENT}

Change in responsibilities at work

Son or daughter leaving home

Trouble with in-laws

Outstanding personal achievement

Wife begin or stop work

Begin or end school

Change in living conditions

Revision of personal habits

Trouble with boss

Change in work hours or conditions

Change in residence

Change in schools

Change in recreation

Change in church activities

Change in social activities

Mortgage or loan less than $\$ 10,000$

Change in sleeping habits

Change in number of family get-togethers

Change in eating habits

Vacation

Christmas

Minor violations of the law 


\section{PILOT STUDY QUESTIONNAIRE}

1. Please give us a little background about your situation.

2. What were your initial feel ings upon your husband's death?

3. What types of problems did you experience after your husband's death?

4. Who provided you with immediate help? What was helpful?

5. Who did not provide you with the help that you wanted?

6. What would you have liked that you did not receive?

7. What do you define as your support system?

8. What is the biggest problem you are experiencing now?

9. What do you think the community needs?

10. What type of advice would you give to new widows? 


\section{QUESTIONNAIRE}

AGE

SEX

YEARS MARRIED

HUSBAND'S EDUCATIONAL LEVEL

HUSBAND'S OCCUPATION

HUSBAND'S LAST ANNUAL INCOME

PRESENT ANNUAL INCOME
LENGTH OF TIME WIDOWED

NUMBER OF CHILDREN

CHILDREN LIVING AT HOME

WIFE'S EDUCATIONAL LEVEL

WIFE'S OCCUPATION

WIFE'S LAST ANNUAL INCOME

1. What were the 3 most difficult adjustments you have had to face as being a widow?

2. Was anything helpful in adjusting to the above stated difficulties?

2a. If yes, what was helpful?

2b. If no, what could have been helpful?

We would now like you to indicate how you see yourself in reference to the following questions, based on this scale of 1 to 6 :
1 strongly agree
2. moderately agree
3 agree
4 disagree
5 moderately disagree
6 strongly disagree

3. I am satisfied with how often I get out of the house alone. 3. 3a. Approximately how many times a week do you get out of the house alone?

3b. Where are some places you go? 
4. I am satisfied with how often I am getting out of the house with others.

4.

4a. Approximately how many times a week do you get out of the house with others?

$4 b$. Where are some places you go?

5. I am satisfied with how often I invite my friends over.

5.

5a. Approximately how many times do you invite your friends over?

5b. What types of activities do you do with your friends?

6. I am satisfied with the amount of family contact I have (letters, phone calls and personal visits).

6.

6a. What is the approximate amount of family contact weekly:

1. letters

2. phone calts

3. personal visits

6b. Where is your immediate family (children, parents, brothers, sisters) living?

6c. If there was family contact with your in-laws before your husband's death, has it increased, decreased, or stayed the same since his death?

7. I am satisfied with my ability to express my feelings about being a widow to others.

7.

8. I am satisfied with the willingness of others to listen to me express my feelings about being a widow.

8.

9. My thoughts are oriented to the:

9a. past

9 a.

1. What are your primary thoughts concerning the past?

9b. present

9b.

1. What are your primary thoughts concerning the present? 
9c. future

9c.

1. What are your plans for the future?

10. I am depressed.

10.

10a. What are you depressed about?

10b. Give Zung Depression Test.

11. I was satisfied with my relationship with my husband.

11.

12. I was dependent on my husband for:

12a. economic support

$12 a$.

1. please elaborate.

-12b. emotional support

$12 b$.

1. please elaborate.

13. During the 6 months prior to my husband's death and 6 months after my husband's death, my heal th has changed.

13.

13a. If it has changed, how has it changed?

14. Since I becarne a widow, I learned to drive. yes _ no __ does not apply (I already knew how to drive) 14a. If yes, what were the reasons for learning how to drive?

15. Since I became a widow, I am taking courses in school. yes husband's death) does not apply (I was taking courses before 15a. If yes, what were your reasons for taking courses? 15b. If yes, what types of courses are you taking?

16. Since I became a widow, I have started new hobbies. yes no 
16a. If yes, what are your new hobbies?

17. Since I became a widow, I started working. yes _ no __ does not apply (I was already working)

17a. If yes, what was your reason for obtaining a job?

18. What would you like to see in Portland that would be helpful to widows?

19. Do you belong to a widowhood program? yes no

19a. If yes, what were your initial reasons for joining?

19b. If yes, what have you found helpful about the program?

19c. If yes, what would you like to see that the program does not presently have?

19d. If no, do you have any reasons for not belonging?

20. What advice would you give to new widows? 